\title{
Copper-Free One-Pot Sonogashira-Type Coupling for the Efficient Preparation of Symmetric Diarylalkyne Ligands for Metal-Organic Cages**
}

\author{
Marc Lehr ${ }^{+}{ }^{[a]}$ Tobias Paschelke ${ }^{+}{ }^{[a]}$ Victoria Bendt, ${ }^{[a]}$ André Petersen, ${ }^{[a]}$ Lorenz Pietsch, ${ }^{[a]}$ \\ Patrick Harders, ${ }^{[a]}$ and Anna J. McConnell ${ }^{*[a]}$
}

The often time-consuming and challenging multi-step synthesis of ligands for metal-organic cages is a limiting factor for the discovery and application of new cages. We report a highly efficient copper-free one-pot Sonogashira-type coupling for the preparation of symmetric diarylalkyne ligands on both a small and large scale; bipyridine- and benzimidazole-based ligands

\section{Introduction}

Palladium-catalyzed cross-coupling reactions are powerful synthetic methods for carbon-carbon bond formation in modern organic chemistry. ${ }^{[1]}$ In particular, Sonogashira cross-coupling reactions ${ }^{[2]}$ have been used extensively for the synthesis of diarylalkynes in natural products, ${ }^{[3]}$ conjugated oligomers/ polymers in materials science ${ }^{[4]}$ and ligands/building blocks ${ }^{[5]}$ in coordination chemistry and supramolecular chemistry due to their typically high yields and tolerance of a wide range of functional groups.

Symmetric diarylalkynes find application in diverse fields since they are precursors in the synthesis of hexaarylbenzene derivatives, ${ }^{[6]}$ building blocks for light-emitting materials, ${ }^{[7]}$ and inorganic heterocycles ${ }^{[8]}$ as well as building blocks in supramolecular architectures. ${ }^{[5 b, c, f]}$ However, their preparation is typically a multi-step synthesis (black route, Scheme 1), often involving long reaction times and multiple purification steps, resulting in overall lower yields and making scale-up for applications difficult. ${ }^{[7]}$ Glaser coupling ${ }^{[9]}$ can also take place in the presence of the copper co-catalyst with traces of oxygen, leading to side-product formation ${ }^{[2,10]}$ and difficult purifications.

[a] M. Lehr, ${ }^{+}$T. Paschelke, ${ }^{+}$V. Bendt, A. Petersen, L. Pietsch, P. Harders, Prof. Dr. A. J. McConnell Otto Diels Institute of Organic Chemistry

Christian-Albrechts-Universität zu Kiel

Otto-Hahn-Platz 4, Kiel 24098, Germany

E-mail: amcconnell@oc.uni-kiel.de

https://www.otto-diels-institut.de/mcconnell

$\left[{ }^{+}\right]$These authors contributed equally

$\left[{ }^{* *}\right]$ A previous version of this manuscript has been deposited on a preprint server (DOI: doi.org/10.26434/chemrxiv.13625783.v1)

Supporting information for this article is available on the WWW under https://doi.org/10.1002/ejoc.202100275

우 $\odot 2021$ The Authors. European Journal of Organic Chemistry published by Wiley-VCH GmbH. This is an open access article under the terms of the Creative Commons Attribution License, which permits use, distribution and reproduction in any medium, provided the original work is properly cited. for the self-assembly of $\mathrm{Co}_{4} \mathrm{~L}_{6}$ cages were synthesized in short reaction times and high isolated yields directly from aryl halide precursors. This one-pot method reduces the synthetic burden of ligand synthesis and will facilitate the preparation of ligands with additional functionality for applications of their corresponding cages.

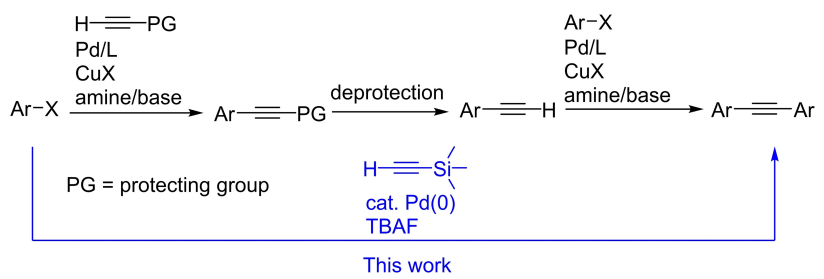

Scheme 1. Multi-step synthesis of diarylacetylenes via sequential Sonogashira cross-coupling reactions (black) and the copper-free one-pot Sonogashira method (blue) in this work.

As a result, one-pot cross-coupling methods using a variety of acetylene sources (e.g. gaseous acetylene, ${ }^{[11]}$ calcium carbide, ${ }^{[12]}$ propiolic acid ${ }^{[13]}$ and silyl-protected alkynes ${ }^{[14]}$ ) as well as copper-free Sonogashira-type couplings ${ }^{[12-13,14 b, 15]}$ (e.g. replacing the copper co-catalyst and amine with tetrabutylammonium fluoride $(T B A F)^{[15 a, b]}$ ) have been developed to overcome these problems, respectively.

Ligand synthesis is a bottleneck for the self-assembly and application of metal-organic cages ${ }^{[5 g-m]}$ due to multi-step syntheses and challenging purifications. Diarylalkyne-based ligands are appealing given their potential synthesis via a onepot procedure and further functionalisation via the alkyne functionality, e.g. through post-assembly modification. ${ }^{[5 c]}$ However, most one-pot Sonogashira couplings have been reported for symmetric carbocyclic rather than heterocyclic diarylalkynes with limited examples including those based on thiophene $\mathrm{e}^{[11-12,14 b, c]}$ and pyridine $\mathrm{e}^{[12,14]}$ derivatives.

We report the efficient synthesis of symmetric diarylalkyne ligands $\mathbf{1} \mathbf{a}-\mathbf{c}$ and $\mathbf{2}$ b-c for metal-organic cages $\mathbf{3} \mathbf{a}-\mathbf{c}$ and $\mathbf{4} \mathbf{a}-\mathbf{b}$ (Figure 1) via a copper-free one-pot procedure using trimethylsilylacetylene as the acetylene source and TBAF functioning as a base, activator, and deprotection reagent (blue route, Scheme 1). In addition to significantly reducing the synthetic burden from a 3 step synthesis with a long overall reaction time to a single 3-hour step, the ligands were prepared in high 

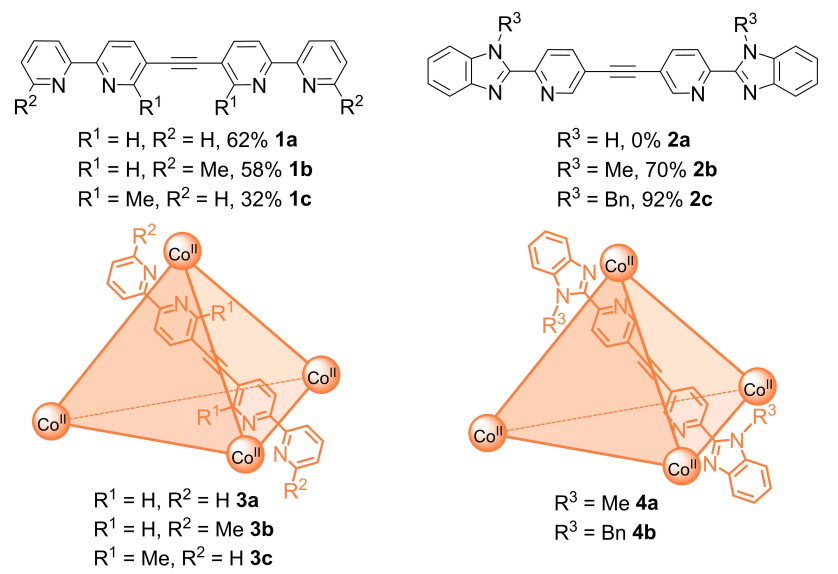

Figure 1. Symmetric heterocyclic diarylalkyne ligands synthesized using the copper-free one-pot Sonogashira-type coupling and their respective $\mathrm{Co}_{4} \mathrm{~L}_{6}$ metal-organic cages.

isolated yields (32-92\%) for a one-pot procedure. The proof-ofprinciple for large-scale ligand synthesis was also demonstrated. Thus, this method enables rapid access to ligands for metalorganic cages from suitable aryl halide building blocks and this will facilitate the discovery of new cages as well as the translation of cages to applications.

\section{Results and Discussion}

We recently reported that the synthesis of ligand $1 \mathrm{a}^{[16]}$ could be reduced from three to two steps using TBAF for the in situ deprotection of the TMS-protected alkyne (first step in black route, Scheme 2). ${ }^{[5]}$ However, the Glaser by-product was also obtained in the final Sonogashira coupling using copper(I)

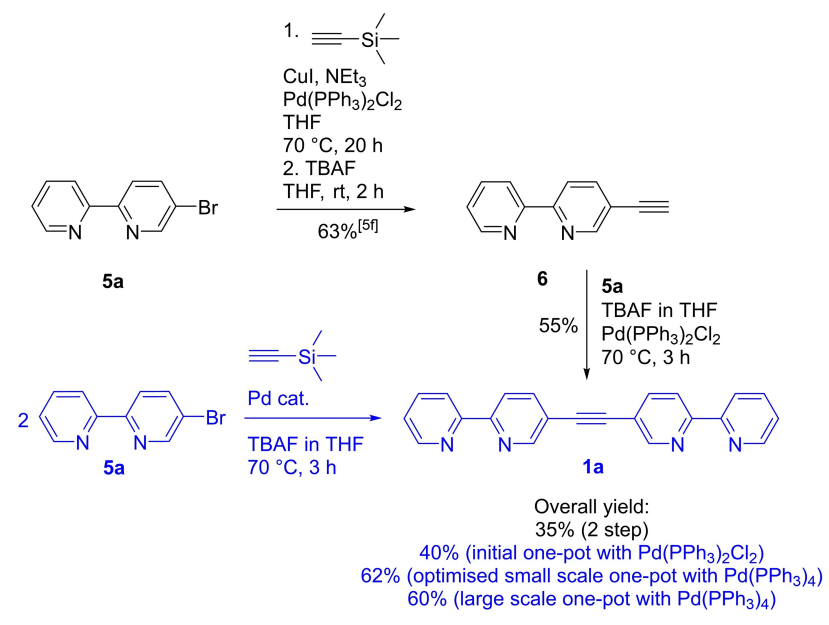

Scheme 2. Development of the copper-free one-pot synthesis of ligand 1 a from 5 a: proof-of-principle for the use of TBAF as a deprotection reagent and activator in a 2 step synthesis (black route); yield and reaction time improvements through a one-pot approach and reaction optimization (blue route). iodide in some instances. Mori ${ }^{[15 a]}$ and $\mathrm{Li}^{[15 b]}$ reported copperand amine-free Sonogashira couplings between terminal alkynes and aryl halides, including aryl chlorides, with short reaction times and good to excellent yields using TBAF as an activator. It is proposed that the TBAF activates and stabilizes the $\operatorname{Pd}(0)$ species, deprotonates the alkyne, and acts as a phasetransfer catalyst. ${ }^{[15 b]}$ Therefore, we envisaged TBAF could play the role of not only a deprotection reagent but also an activator and base in a one-pot procedure while preventing the formation of Glaser by-products.

Firstly, we investigated the applicability of the Sonogashiratype coupling using TBAF to heterocyclic diarylalkynes by reacting 5 a with $6^{[5]}$ (second step in black route, Scheme 2). The previously reported Sonogashira coupling ${ }^{[5]}$ reaction conditions for 1 a were initially adapted replacing the copper(I) iodide and amine with a commercially available TBAF solution in THF. Since this would function as both a reagent and solvent, an excess of TBAF was used compared to the previously reported methods of Mori ${ }^{[15 a]}$ and $\mathrm{Li}^{[15 \mathrm{~b}]}$ to ensure both sufficient TBAF was present for its multiple roles in the reaction and a suitable reaction volume. Ligand 1 a was obtained with full conversion of $\mathbf{5} \mathbf{a}$ within a shorter reaction time of 3 hours in $55 \%$ isolated yield following column chromatography. Taking into account the $63 \%$ yield for the synthesis of $6,^{[5 f]}$ the overall yield of ligand $1 \mathrm{a}$ from $5 \mathrm{a}$ via the two sequential crosscouplings is $35 \%$ (Scheme 2 ).

Having demonstrated that TBAF functions in both the deprotection and Sonogashira-type steps (black route, Scheme 2), the one-pot synthesis of ligand 1 a was carried out under analogous conditions, using 1 eq. of $5 \mathrm{a}$ and 0.5 eq. of TMSA (blue route, Scheme 2). Ligand 1 a was isolated in $40 \%$ yield and $12 \%$ of the starting material 5 a was also recovered (Table 1, entry 1 ). This with the observation of intense gas release upon addition of TBAF suggested immediate deprotection of TMSA's silyl protecting group, resulting in the release of gaseous acetylene. While no starting material was recovered upon increasing the TMSA to 1 eq., a similar yield was obtained (Table 1, entry 2).

The reaction vessel was then changed to a pressure tube to investigate if acetylene loss over the course of the reaction was significant. While the yield did not improve with a stoichiometric amount of TMSA (Table 1, entry 3 ), the yield could be improved to $53 \%$ by using an excess of TMSA (Table 1, entry 4 ). In entries 1-4 the reactions were carried out under a nitrogen

\begin{tabular}{|c|c|c|c|}
\hline Entry & TMSA (eq.) & Reaction Vessel & Yield $^{[c]}[\%]$ \\
\hline 1 & 0.5 & RBF & 40 \\
\hline 2 & 1 & RBF & 35 \\
\hline 3 & 0.5 & PT & 40 \\
\hline 4 & 1 & PT & 53 \\
\hline $5^{[b]}$ & 1 & PT & 54 \\
\hline
\end{tabular}

[a] Reaction conditions: 1 eq. 5 a $(723 \mu \mathrm{mol}), 5 \mathrm{~mol} \% \mathrm{Pd}\left(\mathrm{PPh}_{3}\right)_{2} \mathrm{Cl}_{2}, 6$ eq. $1 \mathrm{M}$ TBAF in THF (not degassed), $\mathrm{N}_{2}$ atmosphere. RBF = round bottom flask, $\mathrm{PT}=$ pressure tube. [b] Degassed $1 \mathrm{M}$ TBAF in THF. [c] Isolated yield after column chromatography. 
atmosphere without degassing the TBAF solution in THF before addition to the reagents. Degassing of the TBAF solution by bubbling nitrogen was unnecessary as a similar yield was obtained when this additional step was performed (Table 1, entry 5).

In an effort to optimize the yield further, various palladium catalysts were screened (Table 2). Compared to $\mathrm{Pd}\left(\mathrm{PPh}_{3}\right)_{2} \mathrm{Cl}_{2}$ (Table 2, entry 1 ), the catalysts $\mathrm{Pd}(\mathrm{OAC})_{2}$ (Table 2, entry 2 ) and $\mathrm{Pd}(\mathrm{dppf}) \mathrm{Cl}_{2}$ (Table 2, entry 3 ) gave lower yields. However, the reaction with $\mathrm{Pd}\left(\mathrm{PPh}_{3}\right)_{4}$ (Table 2, entry 4 ) gave the product in an improved yield of $62 \%$. As a precaution, the TBAF solution for this reaction was degassed due to the oxygen sensitivity of the catalyst. ${ }^{[17]}$

Further experiments were carried out to investigate if the reaction parameters (time, temperature, catalytic loading, aryl halide reactivity) can be reduced without significantly impacting the yield (Table 3 ). With a 1 hour instead of a 3 hour reaction time, ligand $1 \mathrm{a}$ was still isolated in good yield and no starting material was recovered (Table 3, entry 2). However, reducing the reaction time further to $30 \mathrm{~min}$ led to a significant decrease in the yield, and $40 \%$ of the starting material was recovered (Table 3 , entry 3 ). Heating the reaction was necessary since the coupling did not take place at room temperature and $98 \%$ of the starting material was recovered, even with a longer reaction time of 20 hours (Table 3, entry 4). Although a ten-fold lower catalytic loading of $0.5 \mathrm{~mol} \%$ still gave 1 a in $32 \%$ yield, the reaction was not complete within 3 hours since $41 \%$ of the starting material was recovered (Table 3, entry 5). Given the short reaction time with aryl bromide $1 \mathrm{a}$, the one-pot procedure was also extended to the less reactive aryl chloride $\mathbf{5 d}$ (SI, Section S2.1.2) but no product was obtained (Scheme S2).

\begin{tabular}{|c|c|c|c|c|}
\hline Entry & Pd catalyst & Temp. $\left[{ }^{\circ} \mathrm{C}\right]$ & Time [h] & Yield $^{[\mathrm{cc}]}[\%]$ \\
\hline 1 & $\mathrm{Pd}\left(\mathrm{PPh}_{3}\right)_{2} \mathrm{Cl}_{2}$ & 70 & 3 & 53 \\
\hline 2 & $\mathrm{Pd}(\mathrm{OAc})_{2}$ & 70 & 3 & 13 \\
\hline 3 & $\mathrm{Pd}(\mathrm{dppf}) \mathrm{Cl}_{2}$ & 70 & 3 & 40 \\
\hline $4^{[\mathrm{b}]}$ & $\mathrm{Pd}\left(\mathrm{PPh}_{3}\right)_{4}$ & 70 & 3 & 62 \\
\hline
\end{tabular}

[a] Reaction conditions: 1 eq. 5 a $(723 \mu \mathrm{mol}), 1$ eq. TMSA, $5 \mathrm{~mol} \% \mathrm{Pd}$ catalyst, 6 eq. non-degassed $1 \mathrm{M}$ TBAF in THF, pressure tube, $\mathrm{N}_{2}$ atmosphere. [b] Degassed $1 \mathrm{M}$ TBAF in THF. [c] Isolated yield after column chromatography.

Table 3. Catalyst loading, temperature and reaction time screening of one-pot Sonogashira-type experiments for the preparation of $\mathbf{1}$ a from $\mathbf{5} \mathrm{a}^{[\mathrm{a]}}$

\begin{tabular}{|lllll|} 
Entry & Pd cat. [mol\%] & Temp. $\left[{ }^{\circ} \mathrm{C}\right]$ & Time $[\mathrm{h}]$ & Yield $^{[\mathrm{b}]}[\%]$ \\
\hline 1 & 5 & 70 & 3 & 62 \\
2 & 5 & 70 & 1 & 50 \\
3 & 5 & 70 & 0.5 & $23(40)^{[\mathrm{c}]}$ \\
4 & 5 & $\mathrm{rt}$ & 20 & $0(98)^{[\mathrm{cc}}$ \\
5 & 0.5 & 70 & 3 & $32(41)^{[\mathrm{c}]}$ \\
\hline
\end{tabular}

[a] Reaction conditions: 1 eq. 5 a $(723 \mu \mathrm{mol}), \mathrm{Pd}\left(\mathrm{PPh}_{3}\right)_{4}, 1$ eq. TMSA, 6 eq. degassed $1 \mathrm{M}$ TBAF in THF, pressure tube, $\mathrm{N}_{2}$ atmosphere. [b] Isolated yield after column chromatography. [c] Recovered $\mathbf{5}$ a.
Through the development and optimization of the copperfree one-pot procedure, ligand $\mathbf{1}$ a can now be prepared both more efficiently and without the formation of Glaser byproducts. $\mathrm{Li}$ and co-authors proposed a mechanism for TBAF promoted cross-couplings ${ }^{[15 b]}$ and we propose a similar mechanism for the one-pot procedure. Compared to the previous 3 step synthesis of ligand 1 a with a total reaction time over 40 hours $^{[16 a, b, 18]}$ this one-pot procedure gives the ligand after a significantly reduced overall reaction time of 3 hours. Although a shorter reaction time is possible, 3 hours was chosen for subsequent experiments to ensure full consumption of the starting material.

Furthermore, the overall isolated ligand yield has been significantly improved from $35 \%$ for the shortened 2 step synthesis (black route, Scheme 2) and $40 \%$ yield in initial onepot experiments to $62 \%$ yield following optimization (blue route, Scheme 2). Although no starting material was observed in the ${ }^{1} \mathrm{H}$ NMR spectra of crude reaction mixtures, the yield of each step in the one-pot procedure is not quantitative and product losses are also attributed to purification steps. The optimized yield of $62 \%$ corresponds to an average yield of $85 \%$ for each of the 3 steps (Scheme 1). Finally, the scalability of the procedure was investigated by increasing the reaction scale ten-fold to $1.7 \mathrm{~g}$ of $1 \mathrm{a}$. A similar isolated yield of $60 \%$ was obtained following a chromatography-free purification (Scheme 2).

Having optimized the one-pot conditions for the synthesis of $1 \mathrm{a}$, we extended the reaction scope to the related ligands $1 \mathrm{~b}, 1 \mathrm{c}$, and $\mathbf{2}$ a based on 6-methyl-2,2'-bipyridine and benzimidazole coordination motifs, respectively (Figure 1 ). Ligand $\mathbf{1} \mathbf{b}$ was synthesized in a comparable yield to 1 a (Table 4, entry 1 ), whereas 1 c was obtained in a lower yield even with a longer reaction time of $24 \mathrm{~h}$ (Table 4 , entry 2), attributed to a steric clash of the methyl substituent in close proximity to the crosscoupling site (Scheme 3).

The synthesis of $\mathrm{NH}$-benzimidazole $\mathbf{2}$ a was attempted using the same conditions (Scheme 4), however, only starting material was recovered (Table 4, entry 3 ). We proposed deprotonation of the imidazole under the basic conditions prevented the coupling taking place and therefore, the $\mathrm{NH}$ was substituted with a methyl (6b) or benzyl (6c) group (Scheme 4). Indeed, ligands 2 b (Table 4, entry 4) and 2 c (Table 4, entry 5) were isolated in good to excellent yields. ${ }^{[19]}$ Finally, ligands $\mathbf{1} \mathbf{b}, \mathbf{c}$ and

\begin{tabular}{|c|c|c|c|c|}
\hline Entry & $\mathrm{Ar}-\mathrm{Br}$ & Ligand & Time [h] & Yield [\%] \\
\hline 1 & $5 b$ & $1 \mathrm{~b}$ & 3 & $58^{[\mathrm{b}]}$ \\
\hline 2 & $5 \mathrm{C}$ & $1 \mathrm{c}$ & 24 & $32^{[b]}$ \\
\hline 3 & $6 a$ & $2 a$ & 3 & - \\
\hline 4 & $6 \mathrm{~b}$ & $2 b$ & 3 & $92^{[\mathrm{c}]}$ \\
\hline 5 & $6 c$ & $2 c$ & 3 & $70^{[c]}$ \\
\hline
\end{tabular}

[a] Reaction conditions: 1 eq. $\mathrm{Ar}-\mathrm{Br}(723 \mu \mathrm{mol}), 5 \mathrm{~mol} \% \mathrm{Pd}\left(\mathrm{PPh}_{3}\right)_{4}, 1$ eq. TMSA, 6 eq. degassed $1 \mathrm{M}$ TBAF in THF, $70^{\circ} \mathrm{C}$, pressure tube, $\mathrm{N}_{2}$ atmosphere. [b] Isolated yield after column chromatography. [c] Product precipitated from the reaction mixture. 


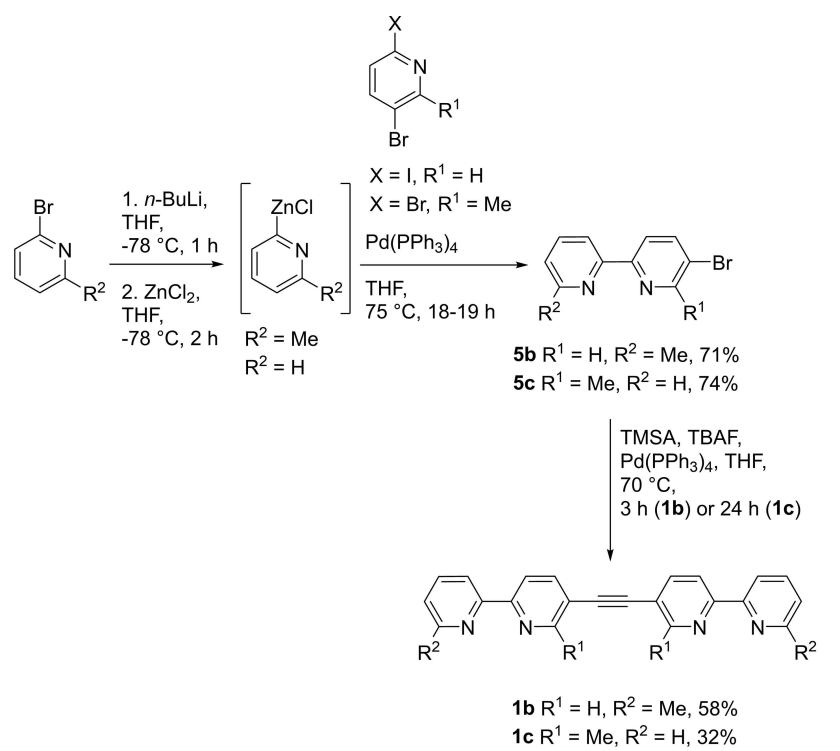

Scheme 3. Synthesis of 6-methyl-2,2'-bipyridine-based ligands $\mathbf{1 b}$ and $1 \mathrm{c}$ via the copper-free one-pot procedure.

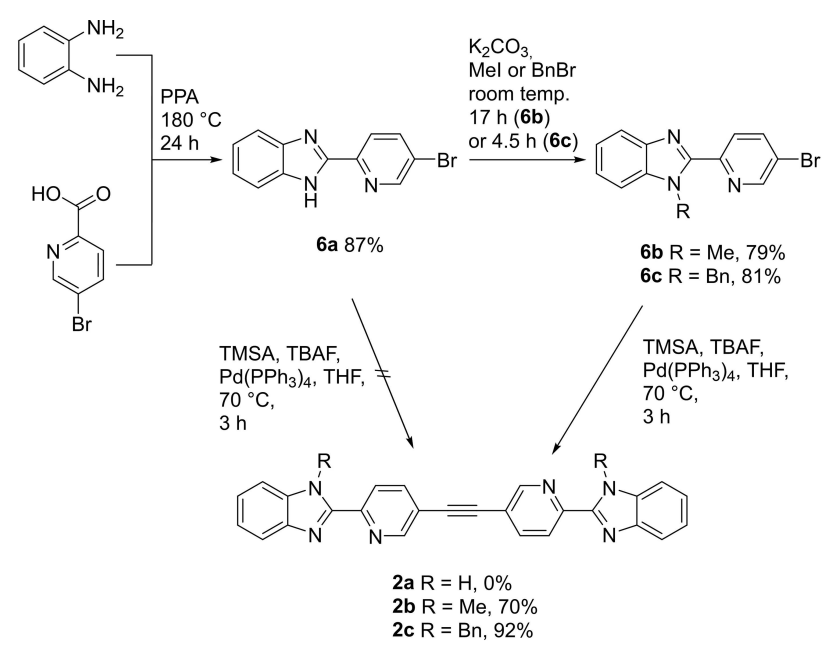

Scheme 4. Synthesis of benzimidazole-based ligands $2 \mathrm{~b}$ and $2 \mathrm{c}$ via the copper-free one-pot procedure.

$2 \mathbf{b}, \mathbf{c}$ synthesised from the one-pot procedure were used for the self-assembly of $\mathrm{Co}_{4} \mathrm{~L}_{6}$ cages $\mathbf{3} \mathbf{b}, \mathbf{c}$ and $\mathbf{4} \mathbf{a}$, $\mathbf{b}$ (Figures $\mathrm{S} 55-81$ ).

\section{Conclusion}

In summary, we have reported a copper-free one-pot Sonogashira-type procedure for the preparation of symmetric heterocyclic diarylalkynes. We have applied this method to the synthesis of ligands $\mathbf{1} \mathbf{a}-\mathbf{c}$ and $\mathbf{2} \mathbf{b}-\mathbf{c}$, which can be used to selfassemble a series of novel metal-organic cages $\mathbf{3} \mathbf{b}-\mathbf{c}$ and $\mathbf{4} \mathbf{a}-\mathbf{b}$. This procedure has the following advantages: reduction of a 3 step synthesis to 1 step; good to excellent isolated yields (32$92 \%)$ for a one-pot synthesis; short reaction times of typically
3 hours; scalability; copper-free conditions preventing the formation of Glaser side-products; commonly used reagents that are commercially available and relatively inexpensive.

This one-pot procedure now enables rapid access to symmetric diarylalkynes ligands directly from aryl halide substrates both on a small and large scale. This reduces the synthetic burden for scale-up as well as incorporating additional functionality for applications. Libraries of ligands could also be generated for high-throughput screening of self-assembly conditions enabling the discovery of new cages. Given the application of symmetric diarylalkynes in numerous fields, this straightforward copper-free one-pot procedure could also be extended to other carbocyclic and heterocyclic aryl halide substrates and allow scale-up for applications.

\section{Experimental Section}

Material and Methods. Solvents and reagents were commercially obtained and used without further purification. Anhydrous tetrahydrofuran was dried using a Pure Solv MD-5 apparatus from Innovative Technologies. Tetrabutylammonium fluoride (1 $\mathrm{M}$ in tetrahydrofuran) for use in reactions with $\mathrm{Pd}\left(\mathrm{PPh}_{3}\right)_{4}$ was degassed by bubbling nitrogen through the solution for $24 \mathrm{~h}$ ensuring solvent evaporation did not affect the reagent's concentration. $\mathrm{Pd}\left(\mathrm{PPh}_{3}\right)_{4}$ was stored under a nitrogen atmosphere due to its air sensitivity. Pressure tubes $(15 \mathrm{~mL})$ were purchased from FengTecEx $\mathrm{GmbH}$ and as a precaution, the reactions using pressure tubes were performed behind a blast shield.

For thin-layer chromatography, Macherey Nagel plates (Polygram ${ }^{\circledR}$ SIL G/UV 254 , coating thickness $0.2 \mathrm{~mm}$ ) equipped with a fluorescence indicator were used. Silica gel with a pore diameter of 0.040-0.063 mm was purchased from Merck. For flash chromatography Biotage ${ }^{\oplus}$ SNAP Ultra columns $(10 \mathrm{~g}, 25 \mathrm{~g}, 50 \mathrm{~g})$ and Biotage ${ }^{\circledast}$ Sfär Silica HC D columns (10 g, $25 \mathrm{~g})$ were used on an Isolera One from Biotage ${ }^{\oplus}$.

Synthetic Procedures. Compound 6 was prepared according to a literature procedure ${ }^{[5 f]}$ and the synthesis of ligands $\mathbf{1} \mathbf{a}-\mathbf{c}, \mathbf{2} \mathbf{b}-\mathbf{c}$ and their precursors $5 \mathrm{a}-\mathrm{c}, \mathbf{6} \mathrm{a}-\mathrm{c}$ are detailed below. Procedures for the preparation and characterization of metal-organic cages $3 \mathrm{a}-\mathrm{c}$ and $\mathbf{4} \mathbf{a}-\mathbf{b}$ are provided in the Supplementary Information.

5-Bromo-2, $2^{\prime}$-bipyridine (5 a): Adapted from literature procedure. ${ }^{[5 \mathrm{~h}]}$ Under a nitrogen atmosphere 2-iodo-5-bromopyridine $(2.00 \mathrm{~g}$, $7.04 \mathrm{mmol})$ and $\mathrm{Pd}\left(\mathrm{PPh}_{3}\right)_{4}(408 \mathrm{mg}, 5 \mathrm{~mol} \%)$ were dissolved in $\mathrm{a}$ solution of 2-pyridylzinc(II) bromide $(0.5 \mathrm{M}$ in tetrahydrofuran, $14.0 \mathrm{~mL}, 7.00 \mathrm{mmol}$ ). The reaction mixture was heated at $75^{\circ} \mathrm{C}$ for $20 \mathrm{~h}$. After cooling to room temperature, sat. ethylenediaminetetraacetic acid $(20 \mathrm{~mL})$ and sat. sodium bicarbonate solution $(20 \mathrm{~mL})$ were added and the reaction mixture was stirred at room temperature for another $2 \mathrm{~h}$. The aqueous layer was extracted with dichloromethane $(3 \times 150 \mathrm{~mL})$, the organic layers were combined, dried over magnesium sulfate and filtered. The solvent was removed in vacuo. The crude product was purified by flash chromatography (silica gel, 5-15\% ethyl acetate/cyclohexane) and the product was obtained as a yellowish solid $(1.19 \mathrm{~g}, 5.06 \mathrm{mmol}$, $72 \%)$. The analytical data was consistent with literature data: ${ }^{[20]}{ }^{1} \mathrm{H}$ NMR $\left(500 \mathrm{MHz}, \mathrm{CDCl}_{3}, 298 \mathrm{~K}, \mathrm{TMS}\right) \delta(\mathrm{ppm}): 8.72\left(\mathrm{~d},{ }^{4} J=2.4 \mathrm{~Hz}, 1 \mathrm{H}\right.$, $\left.H_{\mathrm{j}}\right), 8.67\left(\mathrm{ddd},{ }^{3} \mathrm{~J}=4.8 \mathrm{~Hz},{ }^{4} J=1.8 \mathrm{~Hz}, 5=0.8 \mathrm{~Hz}, 1 \mathrm{H}, H_{\mathrm{a}}\right), 8.38(\mathrm{dt}$, $\left.{ }^{3} J=7.8 \mathrm{~Hz},{ }^{4} J=1.0 \mathrm{~Hz}, 1 \mathrm{H}, H_{\mathrm{d}}\right), 8.33\left(\mathrm{~d},{ }^{3} J=8.5 \mathrm{~Hz}, 1 \mathrm{H}, H_{\mathrm{g}}\right), 7.94(\mathrm{dd}$, $\left.{ }^{3} J=8.5 \mathrm{~Hz},{ }^{4} J=2.4 \mathrm{~Hz}, 1 \mathrm{H}, H_{\mathrm{h}}\right), 7.83\left(\mathrm{td},{ }^{3} J=7.8 \mathrm{~Hz},{ }^{4} J=1.8 \mathrm{~Hz}, 1 \mathrm{H}\right.$, $\left.H_{\mathrm{c}}\right), 7.33$ (ddd, $\left.{ }^{3} J=7.8 \mathrm{~Hz},{ }^{3} \mathrm{~J}=4.8 \mathrm{~Hz},{ }^{4} J=1.2 \mathrm{~Hz}, 1 \mathrm{H}, H_{\mathrm{b}}\right) .{ }^{13} \mathrm{C}$ NMR (126 MHz, CDCl $3,298 \mathrm{~K}, \mathrm{TMS}) \delta$ (ppm): $155.1\left(C_{\mathrm{e}}\right), 154.5\left(C_{\mathrm{f}}\right), 150.2$ 
$\left(C_{\mathrm{j}}\right), 149.2\left(C_{\mathrm{a}}\right), 139.5\left(C_{\mathrm{h}}\right), 137.1\left(C_{\mathrm{c}}\right), 124.0\left(C_{\mathrm{b}}\right), 122.4\left(C_{\mathrm{g}}\right), 121.2\left(C_{\mathrm{i}}\right)$,

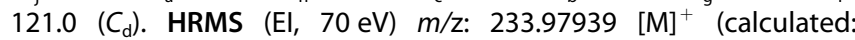
233.97926 for $\mathrm{C}_{10} \mathrm{H}_{7}{ }^{79} \mathrm{Br}_{1} \mathrm{~N}_{2}$ ), 235.97764 [M] ${ }^{+}$(calculated: 235.97721 for $\mathrm{C}_{10} \mathrm{H}_{7}^{81} \mathrm{Br}_{1} \mathrm{~N}_{2}$ ). FT-IR: $\tilde{v}=2360.2(\mathrm{w}), 2248.9(\mathrm{w}), 1586.2(\mathrm{w}), 1570.3$ $(w), 1542.1(\mathrm{~m}), 1496.9(\mathrm{w}), 1458.4(\mathrm{~s}), 1433.5(\mathrm{~m}), 1370.6(\mathrm{w}), 1243.1$ (w), $1145.3(\mathrm{w}), 1090.0(\mathrm{w}), 1061.1(\mathrm{w}), 1021.9(\mathrm{~m}), 992.5(\mathrm{w}), 927.9$ $(w), 905.9(w), 858.2(m), 797.3(s), 749.6(s), 648.9(w), 620.4(w)$, $593.8(w), 564.0(w) \mathrm{cm}^{-1}$. M. p.: $76^{\circ} \mathrm{C}$.

Large Scale Synthesis of 5-Bromo-2,2'-bipyridine (5a): Under a nitrogen atmosphere 2-iodo-5-bromopyridine $(7.10 \mathrm{~g}, 25.0 \mathrm{mmol})$ and $\mathrm{Pd}\left(\mathrm{PPh}_{3}\right)_{4}(1.44 \mathrm{~g}, 5 \mathrm{~mol} \%)$ were dissolved in a solution of 2pyridylzinc(II) bromide $(0.5 \mathrm{M}$ in tetrahydrofuran, $50.0 \mathrm{~mL}$, $25.0 \mathrm{mmol}$ ). The reaction mixture was heated at $75^{\circ} \mathrm{C}$ for $48 \mathrm{~h}$. After cooling to room temperature, sat. ethylenediaminetetraacetic acid $(150 \mathrm{~mL})$ and sat. sodium bicarbonate solution $(150 \mathrm{~mL})$ was added and the reaction mixture was stirred at room temperature for another $24 \mathrm{~h}$. The aqueous layer was extracted with dichloromethane $(3 \times 150 \mathrm{~mL})$, the organic layers were combined, dried over magnesium sulfate, and filtered. The solvent was removed in vacuo. The crude product was purified by flash chromatography (silica gel, $5-15 \%$ ethyl acetate/cyclohexane) and the product was obtained as a yellowish solid $(4.19 \mathrm{~g}, 17.8 \mathrm{mmol}, 71 \%)$.

5-Chloro-2,2'-bipyridine (5d): Under a nitrogen atmosphere 2bromo-5-chloropyridine $(577 \mathrm{mg}, 3.00 \mathrm{mmol})$ and $\mathrm{Pd}\left(\mathrm{PPh}_{3}\right)_{4}$ (173 mg, $5 \mathrm{~mol} \%$ ) were dissolved in a solution of 2-pyridylzinc(II) bromide $(0.5 \mathrm{M}$ in tetrahydrofuran, $6.0 \mathrm{~mL}, 3.00 \mathrm{mmol})$. The reaction mixture was heated at $75^{\circ} \mathrm{C}$ for $18 \mathrm{~h}$. After cooling to room temperature, sat. ethylenediaminetetraacetic acid $(40 \mathrm{~mL})$ and sat. sodium bicarbonate solution $(40 \mathrm{~mL})$ were added and the reaction mixture was stirred at room temperature for another $2 \mathrm{~h}$. The aqueous layer was extracted with dichloromethane $(3 \times 100 \mathrm{~mL})$, the organic layers were combined, dried over magnesium sulfate, and filtered. The solvent was removed in vacuo. The crude product was purified by flash chromatography (silica gel, 5-15\% ethyl acetate/cyclohexane) and the product was obtained as a colourless solid (276 mg, $1.45 \mathrm{mmol}, 48 \%):{ }^{1} \mathrm{H}$ NMR $\left(600 \mathrm{MHz}, \mathrm{CDCl}_{3}, 298 \mathrm{~K}\right.$, TMS) $\delta$ (ppm): 8.66 (unres. ddd, ${ }^{3} J=4.7 \mathrm{~Hz}, 1 \mathrm{H}, H_{\mathrm{a}}$ ), $8.61\left(\mathrm{~d},{ }^{4} J=\right.$ $\left.2.2 \mathrm{~Hz}, 1 \mathrm{H}, H_{\mathrm{j}}\right), 8.37\left(\mathrm{~d},{ }^{3} \mathrm{~J}=8.5 \mathrm{~Hz}, 1 \mathrm{H}, H_{\mathrm{g}}\right), 8.36\left(\mathrm{~d},{ }^{3} J=7.8 \mathrm{~Hz}, 1 \mathrm{H}\right.$, $\left.H_{\mathrm{d}}\right), 7.81\left(\mathrm{td},{ }^{3} J=7.8 \mathrm{~Hz},{ }^{4} J=1.7 \mathrm{~Hz}, 1 \mathrm{H}, H_{\mathrm{c}}\right), 7.78\left(\mathrm{dd},{ }^{3} J=8.5 \mathrm{~Hz},{ }^{4} J=\right.$ $2.2 \mathrm{~Hz}, 1 \mathrm{H}, H_{\mathrm{h}}$ ), 7.32 (ddd, ${ }^{3} J=7.8 \mathrm{~Hz},{ }^{3} J=4.7 \mathrm{~Hz},{ }^{4} J=0.9 \mathrm{~Hz}, 1 \mathrm{H}, H_{\mathrm{b}}$ ). ${ }^{13} \mathrm{C}$ NMR (151 MHz, CDCl, $298 \mathrm{~K}$, TMS) $\delta(\mathrm{ppm}): 155.1\left(C_{\mathrm{e}}\right), 154.3\left(C_{\mathrm{f}}\right)$, $149.2\left(C_{\mathrm{a}}\right), 148.0\left(C_{\mathrm{j}}\right), 137.0\left(C_{\mathrm{c}}\right), 136.7\left(C_{\mathrm{h}}\right), 132.4\left(C_{\mathrm{i}}\right), 124.0\left(C_{\mathrm{b}}\right), 121.9$ $\left(C_{g}\right), 121.0\left(C_{d}\right)$. HRMS (ESI) $\mathrm{m} / \mathrm{z}: 191.03689[\mathrm{M}+\mathrm{H}]^{+}$(calculated: 191.03705 for $\mathrm{C}_{10} \mathrm{H}_{8} \mathrm{~N}_{2} \mathrm{Cl}$ ). M. p.: $76^{\circ} \mathrm{C}$.

1,2-Di([2',2"'-bipyridin]-5'-yl)ethyne (1 a): The analytical data from the various reactions was consistent with literature data. ${ }^{[16 b, c]}$

Procedure for the Optimised One-Pot Reaction in a Pressure Tube: 5-Bromo-2,2'-bipyridine (5a) $(170 \mathrm{mg}, 723 \mu \mathrm{mol})$ and $\mathrm{Pd}$ $\left(\mathrm{PPh}_{3}\right)_{4}$ (41.8 mg, $\left.5 \mathrm{~mol} \%\right)$ were added to a pressure tube and evacuated for five minutes. Using counterflow technique, degassed tetrabutylammonium fluoride $(1 \mathrm{M}$ in tetrahydrofuran, $4.30 \mathrm{~mL}$, $4.30 \mathrm{mmol})$ and trimethylsilylacetylene $(100 \mu \mathrm{L}, 723 \mu \mathrm{mol})$ were added. The pressure tube was immediately closed and the reaction mixture was heated at $70^{\circ} \mathrm{C}$ for $3 \mathrm{~h}$. After cooling to room temperature, the mixture was washed with water $(50 \mathrm{~mL})$ and the aqueous layer was extracted with dichloromethane $(3 \times 33 \mathrm{~mL})$. The organic layers were combined, dried over magnesium sulfate and the solvent removed in vacuo. The crude product was purified by flash chromatography (silica gel, $10-20 \%$ ethyl acetate/ cyclohexane) to give the product as a colourless solid $(74.9 \mathrm{mg}$, $224 \mu \mathrm{mol}, 62 \%)$ : H NMR (500 MHz, CDCl $3,298 \mathrm{~K}, \mathrm{TMS}) \delta$ (ppm): 8.85 $\left(\mathrm{dd},{ }^{4} J=2.2 \mathrm{~Hz},{ }^{5} J=0.8 \mathrm{~Hz}, 2 \mathrm{H}, H_{\mathrm{j}}\right), 8.71\left(\mathrm{ddd},{ }^{3} J=4.8,{ }^{4} J=1.8 \mathrm{~Hz}\right.$, $\left.{ }^{5} J=0.8 \mathrm{~Hz}, 2 \mathrm{H}, H_{\mathrm{a}}\right), 8.47-8.45\left(\mathrm{~m}, 2 \mathrm{H}, H_{\mathrm{g}}\right), 8.45-8.43\left(\mathrm{~m}, 2 \mathrm{H}, H_{\mathrm{d}}\right), 7.99$ $\left(\mathrm{dd},{ }^{3} \mathrm{~J}=8.3 \mathrm{~Hz},{ }^{4} J=2.2 \mathrm{~Hz}, 2 \mathrm{H}, H_{\mathrm{h}}\right), 7.85\left(\mathrm{td},{ }^{3} J=7.7 \mathrm{~Hz},{ }^{4} J=1.8,2 \mathrm{H}\right.$,
$\left.H_{\mathrm{c}}\right), 7.34\left(\mathrm{ddd},{ }^{3} J=7.7 \mathrm{~Hz},{ }^{3} \mathrm{~J}=4.8 \mathrm{~Hz},{ }^{4} J=1.2 \mathrm{~Hz}, 2 \mathrm{H}, H_{\mathrm{b}}\right.$ ). ${ }^{13} \mathrm{C}$ NMR $\left(126 \mathrm{MHz}, \mathrm{CDCl}_{3}, 298 \mathrm{~K}, \mathrm{TMS}\right) \delta(\mathrm{ppm}): 155.3\left(C_{\mathrm{e}}\right), 155.2\left(C_{\mathrm{f}}\right), 151.7$ $\left(C_{\mathrm{j}}\right), 149.2\left(C_{\mathrm{a}}\right), 139.5\left(C_{\mathrm{h}}\right), 137.1\left(C_{\mathrm{c}}\right), 124.1\left(C_{\mathrm{b}}\right), 121.5\left(C_{\mathrm{d}}\right), 120.5\left(C_{\mathrm{g}}\right)$, $119.7\left(C_{\mathrm{i}}\right), \quad 90.5 \quad\left(C_{\mathrm{k}}\right)$. HRMS $(\mathrm{El}, \quad 70 \mathrm{eV}) \quad \mathrm{m} / \mathrm{z}: 334.12117 \quad[\mathrm{M}]^{+}$ (calculated: 334.12185 for $\mathrm{C}_{22} \mathrm{H}_{14} \mathrm{~N}_{4}$ ). FT-IR: $\tilde{v}=2360.2(\mathrm{w}), 2248.9$ $(w), 1586.2(w), 1570.3(w), 1542.1(m), 1496.9(w), 1458.4(s), 1433.5$ $(\mathrm{m}), 1370.6(\mathrm{w}), 1243.1(\mathrm{w}), 1145.3(\mathrm{w}), 1090.0(\mathrm{w}), 1061.1(\mathrm{w})$, $1021.9(\mathrm{~m}), 992.5(\mathrm{w}), 927.9(\mathrm{w}), 905.9(\mathrm{w}), 858.2(\mathrm{~m}), 797.3(\mathrm{~s}), 749.6$ (s), $648.9(w), 620.4(w), 593.8(w), 564.0(w) \mathrm{cm}^{-1}$. M. p.: $228^{\circ} \mathrm{C}$.

Large Scale Procedure for the Optimised One-Pot Reaction in a Pressure Tube: 5-Bromo-2,2'-bipyridine (5 a) $(1.70 \mathrm{~g}, 7.23 \mathrm{mmol})$ and $\mathrm{Pd}\left(\mathrm{PPh}_{3}\right)_{4}(418 \mathrm{mg}, 5 \mathrm{~mol} \%)$ were added to a pressure tube and evacuated for five minutes. Using counterflow technique, degassed tetrabutylammonium fluoride $(1 \mathrm{M}$ in tetrahydrofuran, $43.0 \mathrm{~mL}$, $43.0 \mathrm{mmol})$ and trimethylsilylacetylene $(1.00 \mathrm{~mL}, 7.23 \mathrm{mmol})$ were added. The pressure tube was immediately closed and the reaction mixture was heated at $70^{\circ} \mathrm{C}$ for $3 \mathrm{~h}$. After cooling to room temperature, the precipitate was collected by filtration and was dissolved in dichloromethane $(100 \mathrm{~mL})$ and the organic layer was extracted with hydrochloric acid $(3 \times 30 \mathrm{~mL}, 6 \mathrm{M})$. The layers were separated and the $\mathrm{pH}$ value of the aqueous layer was adjusted to 7 with $25 \%$ ammonia solution and the precipitate was collected (720 mg, $2.15 \mathrm{mmol}, 60 \%$ ).

Procedure for the Coupling of 6 and $5 \mathrm{a}$ in a Round-Bottom Flask: Under a nitrogen atmosphere 5-bromo-2,2'-bipyridine (5a) (85.1 mg, $362 \mu \mathrm{mol}), \quad$ 5-ethynyl-2,2'-bipyridine (6) $(65.2 \mathrm{mg}$, $362 \mu \mathrm{mol})$ and $\mathrm{Pd}\left(\mathrm{PPh}_{3}\right)_{2} \mathrm{Cl}_{2}(25.4 \mathrm{mg}, 10 \mathrm{~mol} \%$, to have the same amount of palladium catalyst as the one-pot conditions) were added to a three-neck flask. Tetrabutylammonium fluoride (1 $\mathrm{M}$ in tetrahydrofuran, $4.30 \mathrm{~mL}, 4.30 \mathrm{mmol}$ ) was added and the reaction mixture heated at $70^{\circ} \mathrm{C}$ for $3 \mathrm{~h}$. After cooling to room temperature water was added, the mixture was extracted with dichloromethane $(3 \times 33 \mathrm{~mL})$, dried over magnesium sulfate and the solvent was removed in vacuo. The crude product was purified by flash chromatography (silica gel, $10-20 \%$ ethyl acetate/cyclohexane) to give 1 a as colorless solid (66.3 mg,198 $\mu \mathrm{mol}, 55 \%)$.

5-Bromo-6'-methyl-2,2'-bipyridine (5 b): Under a nitrogen atmosphere 2-bromo-6-methylpyridine $(1.42 \mathrm{~g}, 8.25 \mathrm{mmol})$ was suspended in anhydrous tetrahydrofuran $(20 \mathrm{~mL})$. The solution was degassed three times using the freeze-pump-thaw technique. Afterwards, the solution was cooled to $-78^{\circ} \mathrm{C}, n$-butyllithium ( $2.5 \mathrm{M}$ in hexane, $3.90 \mathrm{~mL}, 9.75 \mathrm{mmol}$ ) was slowly added and the mixture was stirred at $-78^{\circ} \mathrm{C}$ for $1 \mathrm{~h}$. Zinc(II) chloride $(1 \mathrm{M}$ in tetrahydrofuran, $1.31 \mathrm{~g}, 9.60 \mathrm{~mL}, 9.63 \mathrm{mmol}$ ) was added and the solution was stirred at $-78^{\circ} \mathrm{C}$ for $2 \mathrm{~h}$. At this temperature, 2-iodo-5bromopyridine $(1.95 \mathrm{~g}, 6.87 \mathrm{mmol})$ and $\mathrm{Pd}\left(\mathrm{PPh}_{3}\right)_{4}(398 \mathrm{mg}, 5 \mathrm{~mol} \%)$ were added and the reaction mixture was stirred at $75^{\circ} \mathrm{C}$ for $18 \mathrm{~h}$. After cooling to room temperature, sat. ethylenediaminetetraacetic acid $(50 \mathrm{~mL})$ and sat. sodium bicarbonate solution $(50 \mathrm{~mL})$ were added and the mixture was stirred for further $2 \mathrm{~h}$. The layers were separated, the aqueous layer were extracted with dichloromethane $(3 \times 100 \mathrm{~mL})$, the organic layers were combined, dried over magnesium sulfate and the solvent was removed in vacuo. The crude product was purified by flash chromatography (silica gel, $10 \%$ ethyl acetate/cyclohexane) to obtain the product as a colourless solid (1.21 g, $4.86 \mathrm{mmol}, 71 \%)$ : ${ }^{1} \mathrm{H}$ NMR $\left(500 \mathrm{MHz}, \mathrm{CDCl}_{3}, 298 \mathrm{~K}\right.$, TMS) $\delta$ (ppm): $8.70\left(\mathrm{dd},{ }^{4} J=2.4 \mathrm{~Hz},{ }^{5} J=0.6 \mathrm{~Hz}, 1 \mathrm{H}, H_{\mathrm{k}}\right), 8.33\left(\mathrm{dd},{ }^{3} J=\right.$ $\left.8.4 \mathrm{~Hz},{ }^{5} \mathrm{~J}=0.6 \mathrm{~Hz}, 1 \mathrm{H}, H_{\mathrm{h}}\right), 8.15\left(\mathrm{~d},{ }^{3} J=7.8 \mathrm{~Hz}, 1 \mathrm{H}, H_{\mathrm{e}}\right), 7.92\left(\mathrm{dd},{ }^{3} J=\right.$ $\left.8.4 \mathrm{~Hz},{ }^{4} \mathrm{~J}=2.4 \mathrm{~Hz}, 1 \mathrm{H}, H_{\mathrm{i}}\right), 7.70\left(\mathrm{t},{ }^{3} \mathrm{~J}=7.8 \mathrm{~Hz}, 1 \mathrm{H}, H_{\mathrm{d}}\right), 7.18\left(\mathrm{~d},{ }^{3} \mathrm{~J}=\right.$ $\left.7.8 \mathrm{~Hz}, 1 \mathrm{H}, H_{\mathrm{c}}\right), 2.63\left(\mathrm{~s}, 3 \mathrm{H}, H_{\mathrm{a}}\right) .{ }^{13} \mathrm{C}$ NMR $\left(126 \mathrm{MHz}, \mathrm{CDCl}_{3}, 298 \mathrm{~K}\right.$, TMS) $\delta(p p m): 158.1\left(C_{b}\right), 155.0\left(C_{\mathrm{g}}\right), 154.6\left(C_{\mathrm{f}}\right), 150.1\left(C_{\mathrm{k}}\right), 139.4\left(C_{\mathrm{i}}\right)$, $137.2\left(C_{\mathrm{d}}\right), 123.6\left(C_{\mathrm{c}}\right), 122.5\left(C_{\mathrm{h}}\right), 120.9\left(C_{\mathrm{j}}\right), 118.0\left(C_{\mathrm{e}}\right), 24.6\left(C_{\mathrm{a}}\right)$. HRMS $\left(\mathrm{El}, \quad 70 \mathrm{eV}\right.$ ) $\mathrm{m} / \mathrm{z}: 247.99469 \mathrm{HM}^{+}$(calculated: 247.99491 for $\mathrm{C}_{11} \mathrm{H}_{9}{ }^{79} \mathrm{Br}_{1} \mathrm{~N}_{2}$ ), $249.99278 \quad[\mathrm{M}]^{+} \quad$ (calculated: 249.99286 for $\mathrm{C}_{11} \mathrm{H}_{9}^{81} \mathrm{Br}_{1} \mathrm{~N}_{2}$ ). FT-IR: $\tilde{v}=2920.3(\mathrm{w}), 2307.9(\mathrm{w}), 1751.1(\mathrm{w}), 1593.9$ 
$(\mathrm{w}), 1566.3(\mathrm{~m}), 1547.9(\mathrm{~m}), 1448.8(\mathrm{~m}), 1366.0(\mathrm{~m}), 1285.2(\mathrm{w})$, $1247.9(w), 1154.9(w), 1124.8(w), 1082.1(\mathrm{~m}), 1003.4(\mathrm{~s}), 927.5(\mathrm{w})$, $870.0(\mathrm{w}), 848.3(\mathrm{~s}), 789.6(\mathrm{~s}), 752.9(\mathrm{~s}), 738.3(\mathrm{~m}), 696.4(\mathrm{w}), 656.1$ (w), $631.8(\mathrm{~m}), 595.1$ (m), 540.9 (w), 513.3 (w) cm $\mathrm{cm}^{-1}$. M. p.: $91^{\circ} \mathrm{C}$.

1,2-Di([6"'-methyl-2',2"'-bipyridin]-5'-yl)ethyne (1 b): 5-Bromo-6'methyl-2,2'-bipyridine (5 b) $(180 \mathrm{mg}, 723 \mu \mathrm{mol})$ and $\mathrm{Pd}\left(\mathrm{PPh}_{3}\right)_{4}$ $(41.8 \mathrm{mg}, 5 \mathrm{~mol} \%)$ were added to a pressure tube and evacuated for five minutes. Using counterflow technique, degassed tetrabutylammonium fluoride $(1 \mathrm{M}$ in tetrahydrofuran, $4.30 \mathrm{~mL}, 4.30 \mathrm{mmol}$ ) and trimethylsilylacetylene $(100 \mu \mathrm{L}, 723 \mu \mathrm{mol})$ were added, the pressure tube was immediately closed and the reaction mixture was heated at $70^{\circ} \mathrm{C}$ for $3 \mathrm{~h}$. Upon cooling, the product precipitated and the precipitate was filtered and was washed with cold tetrahydrofuran $(10 \mathrm{~mL})$. The precipitate was dissolved in dichloromethane $(10 \mathrm{~mL})$ and the organic layer was extracted with hydrochloric acid $(3 \times 10 \mathrm{~mL}, 6 \mathrm{M})$. The layers were separated and the $\mathrm{pH}$ value of the aqueous layer was adjusted to 7 with $25 \%$ ammonia solution and the precipitate was collected $(75.3 \mathrm{mg}$, $208 \mu \mathrm{mol}, 58 \%):{ }^{1} \mathrm{H}$ NMR $\left(500 \mathrm{MHz}, \mathrm{CDCl}_{3}, 298 \mathrm{~K}, \mathrm{TMS}\right) \delta$ (ppm): $8.84\left(\mathrm{dd},{ }^{4} J=2.1 \mathrm{~Hz},{ }^{5} J=0.8 \mathrm{~Hz}, 2 \mathrm{H}, H_{\mathrm{k}}\right), 8.48\left(\mathrm{~d},{ }^{3} J=8.2 \mathrm{~Hz}, 2 \mathrm{H}, H_{\mathrm{h}}\right)$, $8.23\left(\mathrm{~d},{ }^{3} J=7.8 \mathrm{~Hz}, 2 \mathrm{H}, H_{\mathrm{e}}\right), 7.96\left(\mathrm{dd},{ }^{3} J=8.2 \mathrm{~Hz},{ }^{4} J=2.1 \mathrm{~Hz}, 2 \mathrm{H}, H_{\mathrm{i}}\right)$, $7.73\left(\mathrm{t},{ }^{3} \mathrm{~J}=7.8 \mathrm{~Hz}, 2 \mathrm{H}, H_{\mathrm{d}}\right), 7.19\left(\mathrm{~d},{ }^{3} \mathrm{~J}=7.8 \mathrm{~Hz}, 2 \mathrm{H}, H_{\mathrm{c}}\right), 2.65(\mathrm{~s}, 6 \mathrm{H}$, $\left.H_{\mathrm{a}}\right) .{ }^{13} \mathrm{C}$ NMR $\left(126 \mathrm{MHz}, \mathrm{CDCl}_{3}, 298 \mathrm{~K}, \mathrm{TMS}\right) \delta(\mathrm{ppm}): 158.1\left(C_{\mathrm{b}}\right), 155.5$ $\left(C_{\mathrm{g}}\right), 154.7\left(C_{\mathrm{f}}\right), 151.7\left(C_{\mathrm{k}}\right), 139.4\left(C_{\mathrm{i}}\right), 137.3\left(C_{\mathrm{d}}\right), 123.7\left(C_{\mathrm{c}}\right), 120.5\left(C_{\mathrm{h}}\right)$, $119.5\left(C_{\mathrm{j}}\right), 118.5\left(C_{\mathrm{e}}\right), 90.4\left(C_{\mathrm{l}}\right), 24.6\left(C_{\mathrm{a}}\right)$. HRMS (El, $\left.70 \mathrm{eV}\right) \mathrm{m} / \mathrm{z}$ : $362.15253 \mathrm{CM}^{+}$(calculated: 362.15315 for $\mathrm{C}_{24} \mathrm{H}_{18} \mathrm{~N}_{4}$ ). FT-IR: $\tilde{v}=$ $2920.9(w), 2359.9(w), 1738.9(w), 1589.9(m), 1568.0(w), 1545.6$ $(\mathrm{m}), 1487.1(\mathrm{w}), 1453.3(\mathrm{~m}), 1372.2(\mathrm{~m}), 1244.7(\mathrm{w}), 1157.0(\mathrm{w})$, $1133.6(w), 1082.9(\mathrm{~m}), 1022.9(\mathrm{w}), 997.9(\mathrm{w}), 983.9(\mathrm{w}), 926.3(\mathrm{w})$, $901.3(\mathrm{w}), 861.9(\mathrm{~s}), 846.3(\mathrm{w}), 799.3(\mathrm{~s}), 754.9(\mathrm{~s}), 693.6(\mathrm{~m}), 644.1$ (m), $598.3(\mathrm{~m}), 553.1(\mathrm{w}), 517.0(\mathrm{w}) \mathrm{cm}^{-1}$. M. p.: $227^{\circ} \mathrm{C}$.

5-Bromo-6-methyl-2,2'-bipyridine (5c): Under a nitrogen atmosphere 2-bromopyridine $(390 \mu \mathrm{L}, 3.90 \mathrm{mmol}$ ) was suspended in anhydrous tetrahydrofuran $(12 \mathrm{~mL})$. The solution was degassed using the freeze-pump-thaw technique. Afterwards, the solution was cooled to $-78^{\circ} \mathrm{C}$, $n$-butyllithium $(2.5 \mathrm{M}$ in hexane, $1.90 \mathrm{~mL}$, $4.75 \mathrm{mmol}$ ) was slowly added and the mixture was stirred at $-78^{\circ} \mathrm{C}$ for $1 \mathrm{~h}$. Zinc(II) chloride (1 M in tetrahydrofuran, $681 \mathrm{mg}$, $5.00 \mathrm{mmol}$ ) was added and the solution was further stirred at $-78^{\circ} \mathrm{C}$ for $2 \mathrm{~h}$. At $-78^{\circ} \mathrm{C}, 3,6$-dibromo-2-methylpyridine $(1.00 \mathrm{~g}$, $3.90 \mathrm{mmol})$ and $\mathrm{Pd}\left(\mathrm{PPh}_{3}\right)_{4}(230 \mathrm{mg}, 5 \mathrm{~mol} \%)$ were added and the reaction mixture was stirred at $75^{\circ} \mathrm{C}$ for $19 \mathrm{~h}$. After cooling to room temperature, sat. ethylenediaminetetraacetic acid $(25 \mathrm{~mL})$ and sat. sodium bicarbonate solution $(25 \mathrm{~mL})$ were added and the mixture was stirred for further $1.5 \mathrm{~h}$. The layers were separated, the aqueous layer was extracted with dichloromethane $(3 \times 50 \mathrm{~mL})$, the organic layers were combined, dried over magnesium sulfate and the solvent was removed in vacuo. The crude product was purified by flash chromatography (silica gel, $5 \%$ ethyl acetate/cyclohexane) to obtain the product as a colourless solid $(714 \mathrm{mg}, 2.87 \mathrm{mmol}, 74 \%)$ : ${ }^{1} \mathrm{H}$ NMR $\left(500 \mathrm{MHz}, \mathrm{CDCl}_{3}, 298 \mathrm{~K}, \mathrm{TMS}\right) \delta(\mathrm{ppm}): 8.66$ (ddd, ${ }^{3} J=$ $\left.4.8 \mathrm{~Hz},{ }^{4} \mathrm{~J}=1.8 \mathrm{~Hz},{ }^{5} \mathrm{~J}=0.9 \mathrm{~Hz}, 1 \mathrm{H}, H_{\mathrm{a}}\right), 8.40\left(\mathrm{dt},{ }^{3} \mathrm{~J}=7.8 \mathrm{~Hz},{ }^{5} \mathrm{~J}=\right.$ $\left.0.9 \mathrm{~Hz}, 1 \mathrm{H}, H_{\mathrm{d}}\right), 8.10\left(\mathrm{~d},{ }^{3} J=8.3 \mathrm{~Hz}, 1 \mathrm{H}, H_{\mathrm{g}}\right), 7.91\left(\mathrm{~d},{ }^{3} J=8.3 \mathrm{~Hz}, 1 \mathrm{H}\right.$, $\left.H_{\mathrm{h}}\right), 7.81\left(\mathrm{td},{ }^{3} J=7.8 \mathrm{~Hz},{ }^{4} J=1.8 \mathrm{~Hz}, 1 \mathrm{H}, H_{\mathrm{c}}\right), 7.31$ (ddd, ${ }^{3} J=7.8 \mathrm{~Hz}$, $\left.{ }^{3} \mathrm{~J}=4.8 \mathrm{~Hz},{ }^{4} \mathrm{~J}=1.2 \mathrm{~Hz}, 1 \mathrm{H}, H_{\mathrm{b}}\right), 2.74\left(\mathrm{~s}, 3 \mathrm{H}, H_{\mathrm{k}}\right) .{ }^{13} \mathrm{C}$ NMR $(126 \mathrm{MHz}$, $\left.\mathrm{CDCl}_{3}, 298 \mathrm{~K}, \mathrm{TMS}\right) \delta(\mathrm{ppm}): 156.6\left(C_{\mathrm{j}}\right), 155.5\left(C_{\mathrm{e}}\right), 154.2\left(C_{\mathrm{f}}\right), 149.1$ $\left(C_{\mathrm{a}}\right), 140.6\left(C_{\mathrm{h}}\right), 137.0\left(C_{\mathrm{c}}\right), 123.8\left(C_{\mathrm{b}}\right), 121.8\left(C_{\mathrm{i}}\right), 121.1\left(C_{\mathrm{d}}\right), 119.9\left(C_{\mathrm{g}}\right)$, $25.2\left(C_{\mathrm{k}}\right)$. HRMS (El, $\left.70 \mathrm{eV}\right) \mathrm{m} / \mathrm{z}: 247.99492$ [M] $^{+}$(calculated: 247.99491 for $\mathrm{C}_{11} \mathrm{H}_{9}{ }^{79} \mathrm{Br}_{1} \mathrm{~N}_{2}$ ), 249.99355 [M] ${ }^{+}$(calculated: 249.99286 for $\mathrm{C}_{11} \mathrm{H}_{9}{ }^{81} \mathrm{Br}_{1} \mathrm{~N}_{2}$ ). FT-IR: $\tilde{v}=2923.9(\mathrm{w}), 2853.05(\mathrm{w}), 1571.8(\mathrm{w})$, $1554.9(\mathrm{~m}), 1419.5(\mathrm{~s}), 1382.5(\mathrm{w}), 1246.8(\mathrm{~m}), 1095.6(\mathrm{~m}), 1029.7(\mathrm{~s})$, $996.0(\mathrm{w}), 977.6(\mathrm{w}), 845.7(\mathrm{~s}), 789.8(\mathrm{~s}), 741.6(\mathrm{~s}), 733.0(\mathrm{~s}), 718.3(\mathrm{~m})$, $620.2(\mathrm{~m}) \mathrm{cm}^{-1}$. M. p.: $88^{\circ} \mathrm{C}$.

1,2-Di([6'-methyl-2',2'-bipyridin]-5'-yl)ethyne (1 c): 5-Bromo-6methyl-2,2'-bipyridine $(5 \mathrm{c}) \quad(180 \mathrm{mg}, 723 \mu \mathrm{mol})$ and $\mathrm{Pd}\left(\mathrm{PPh}_{3}\right)_{4}$
(41.8 $\mathrm{mg}, 5 \mathrm{~mol} \%$ ) were added to a pressure tube and evacuated for five minutes. Using counterflow technique, degassed tetrabutylammonium fluoride ( $1 \mathrm{M}$ in tetrahydrofuran, $4.3 \mathrm{~mL}, 4.30 \mathrm{mmol}$ ) and trimethylsilylacetylene $(100 \mu \mathrm{L}, 723 \mu \mathrm{mol})$ were added, the pressure tube immediately closed and the reaction mixture stirred at $70^{\circ} \mathrm{C}$ for $24 \mathrm{~h}$. After cooling to room temperature, the precipitate was collected by filtration, dissolved in tetrahydrofuran $(200 \mathrm{~mL})$ and the solvent removed in vacuo. The crude product was purified by flash chromatography (silica gel, $20-40 \%$ ethyl acetate/ cyclohexane) to obtain the product as a colourless solid $(42.3 \mathrm{mg}$, $117 \mu \mathrm{mol}, 32 \%):{ }^{1} \mathrm{H}$ NMR (500 MHz, CDCl $\left., 298 \mathrm{~K}, \mathrm{TMS}\right) \delta$ (ppm): $8.69\left(\mathrm{~d},{ }^{3} J=4.9 \mathrm{~Hz},{ }^{4} \mathrm{~J}=1.8 \mathrm{~Hz},{ }^{5} \mathrm{~J}=0.9 \mathrm{~Hz}, 2 \mathrm{H}, H_{\mathrm{a}}\right), 8.47$ (ddd, ${ }^{3} \mathrm{~J}=$ $\left.7.9 \mathrm{~Hz},{ }^{4} J=1.2 \mathrm{~Hz},{ }^{5} J=0.9 \mathrm{~Hz}, 2 \mathrm{H}, H_{\mathrm{d}}\right), 8.27\left(\mathrm{~d},{ }^{3} J=8.1 \mathrm{~Hz}, 2 \mathrm{H}, H_{\mathrm{g}}\right)$, $7.92\left(\mathrm{~d},{ }^{3} \mathrm{~J}=8.1 \mathrm{~Hz}, 2 \mathrm{H}, H_{\mathrm{h}}\right), 7.83\left(\mathrm{td},{ }^{3} J=7.9 \mathrm{~Hz},{ }^{4} \mathrm{~J}=1.8 \mathrm{~Hz}, 2 \mathrm{H}, H_{\mathrm{c}}\right)$, 7.31 (ddd, $\left.{ }^{3} J=7.9 \mathrm{~Hz},{ }^{3} J=4.9 \mathrm{~Hz},{ }^{4} J=1.2 \mathrm{~Hz}, 2 \mathrm{H}, H_{\mathrm{b}}\right), 2.87\left(\mathrm{~s}, 6 \mathrm{H}, H_{\mathrm{k}}\right.$ ). ${ }^{13} \mathrm{C}$ NMR $\left(126 \mathrm{MHz}, \mathrm{CDCl}_{3}, 298 \mathrm{~K}\right) \delta(\mathrm{ppm}): 159.7\left(C_{\mathrm{i}}\right), 155.7\left(C_{\mathrm{e}}\right)$, $154.5\left(C_{\mathrm{f}}\right), 149.3\left(C_{\mathrm{a}}\right), 139.9\left(C_{\mathrm{h}}\right), 136.9\left(C_{\mathrm{c}}\right), 124.0\left(C_{\mathrm{b}}\right), 121.4\left(C_{\mathrm{d}}\right)$, $118.9\left(C_{\mathrm{j}}\right), 118.1\left(C_{\mathrm{g}}\right), 93.7\left(C_{1}\right), 24.1\left(C_{\mathrm{k}}\right)$. HRMS (El, $\left.70 \mathrm{eV}\right) \mathrm{m} / \mathrm{z}$ : $362.15271 \mathrm{MM}^{+}$(calculated: 362.15315 for $\mathrm{C}_{24} \mathrm{H}_{18} \mathrm{~N}_{4}$ ). FT-IR: $\tilde{v}=$ $2987.4(w), 2252.5(w), 1572.1(w), 1546.4(w), 1450.5(m), 1433.8$ $(\mathrm{m}), 1393.1(w), 1246.0(w), 1094.7(w), 1044.0(w), 993.5(w), 848.8$ (m), $794.5(\mathrm{~s}), 747.9(\mathrm{~s}), 718.1(\mathrm{w}), 615.1(\mathrm{~m}) \mathrm{cm}^{-1}$. M. p.: $218^{\circ} \mathrm{C}$.

2-(5'-Bromopyridin-2'-yl)-1H-benzo[d]imidazole (6a): In a threeneck flask polyphosphoric acid $(40 \mathrm{~mL})$ was added and was preheated to $140^{\circ} \mathrm{C}$. o-Phenylenediamine $(1.34 \mathrm{~g}, 12.4 \mathrm{mmol})$ and 5-bromopicolinic acid $(2.50 \mathrm{~g}, 12.4 \mathrm{mmol})$ were added and the reaction mixture was heated at $180^{\circ} \mathrm{C}$ for $24 \mathrm{~h}$. The mixture was cooled to $140^{\circ} \mathrm{C}$, poured into water $(200 \mathrm{~mL})$ and neutralised to $\mathrm{pH} 7$ with ammonia solution ( $25 \%)$. The precipitate was collected by filtration and, after intensive drying in vacuo, the product was obtained as a colourless solid $(2.96 \mathrm{~g}, 10.8 \mathrm{mmol}, 87 \%)$. The analytical data was consistent with literature data: ${ }^{[21]}{ }^{1} \mathrm{H}$ NMR $\left(500 \mathrm{MHz}\right.$, DMSO- $d_{6}, 298 \mathrm{~K} \delta(\mathrm{ppm}): 13.2\left(\mathrm{~s}, 1 \mathrm{H}, H_{\mathrm{a}}\right), 8.86\left(\mathrm{dd},{ }^{4} J=\right.$ $\left.2.3 \mathrm{~Hz},{ }^{5} J=0.8 \mathrm{~Hz}, 1 \mathrm{H}, H_{\mathrm{m}}\right), 8.26\left(\mathrm{dd},{ }^{3} J=8.5 \mathrm{~Hz},{ }^{5} J=0.8 \mathrm{~Hz}, 1 \mathrm{H}, H_{\mathrm{j}}\right)$, $8.23\left(\mathrm{dd},{ }^{3} \mathrm{~J}=8.5 \mathrm{~Hz},{ }^{4} J=2.3 \mathrm{~Hz}, 1 \mathrm{H}, H_{\mathrm{k}}\right), 7.71\left(\mathrm{~d},{ }^{3} J=7.8 \mathrm{~Hz}, 1 \mathrm{H}, H_{\mathrm{c} / f}\right)$, $7.54\left(\mathrm{~d},{ }^{3} \mathrm{~J}=7.8 \mathrm{~Hz}, 1 \mathrm{H}, H_{\mathrm{c} / \mathrm{f}}\right), 7.29-7.18\left(\mathrm{~m}, 2 \mathrm{H}, H_{\mathrm{d}, \mathrm{e}}\right) .{ }^{13} \mathrm{C}$ NMR $\left(126 \mathrm{MHz}\right.$, DMSO- $\left.d_{6}, 298 \mathrm{~K}\right) \delta$ (ppm): $150.0\left(C_{\mathrm{m}}\right), 149.7\left(C_{\mathrm{h}}\right), 147.2\left(C_{\mathrm{i}}\right)$, $143.7\left(C_{\mathrm{b} / \mathrm{g}}\right), 140.1\left(C_{\mathrm{k}}\right), 134.9\left(C_{\mathrm{b} / \mathrm{g}}\right), 123.3\left(C_{\mathrm{d} / \mathrm{e}}\right), 122.9\left(C_{\mathrm{j}}\right), 122.0\left(C_{\mathrm{d} / \mathrm{e}}\right)$, $120.9\left(C_{1}\right), 119.3\left(C_{\mathrm{cff}}\right), 112.0\left(C_{\mathrm{c/f}}\right)$. HRMS (El, $\left.70 \mathrm{eV}\right) \mathrm{m} / \mathrm{z}: 272.98975$ [M] $^{+}$(calculated: 272.99016 for $\left.\mathrm{C}_{12} \mathrm{H}_{8}{ }^{79} \mathrm{Br}_{1} \mathrm{~N}_{3}\right), 274.98788[\mathrm{M}]^{+}$ (calculated: 274.98811 for $\mathrm{C}_{12} \mathrm{H}_{8}{ }^{81} \mathrm{Br}_{1} \mathrm{~N}_{3}$ ). FT-IR: $\tilde{v}=3386(\mathrm{~m}), 3049$ (w), 1422 (s), 1005 (s) $\mathrm{cm}^{-1}$. M. p.: $227^{\circ} \mathrm{C}$.

2-(5'-Bromopyridin-2'-yl)-1-methyl-1H-benzo[d]imidazole (6b): 2(5'-Bromopyridin-2'-yl)-1H-benzo[d]imidazole (6a) (1.60 g, $5.84 \mathrm{mmol}$ ) and potassium carbonate (milled, $2.50 \mathrm{~g}, 18.1 \mathrm{mmol}$ ) were dissolved in dimethylformamide $(25 \mathrm{~mL})$. Methyl iodide $(500 \mu \mathrm{L}, 8.03 \mathrm{mmol}$ ) was added and the reaction mixture was stirred at room temperature for $17 \mathrm{~h}$. Water $(100 \mathrm{~mL})$ was added and the aqueous layer extracted with ethyl acetate $(3 \times 50 \mathrm{~mL})$. The organic layers were combined, washed with brine $(150 \mathrm{~mL})$ and sodium hydroxide solution $(10 \%, 100 \mathrm{~mL})$, dried over magnesium sulfate and the solvent was removed in vacuo. The product was obtained as a greyish solid $(1.33 \mathrm{~g}, 4.62 \mathrm{mmol}, 79 \%)$. The analytical data was consistent with literature data: ${ }^{[22]}{ }^{1} \mathrm{H}$ NMR $\left(600 \mathrm{MHz}\right.$, DMSO- $d_{6}$, $298 \mathrm{~K}) \delta(\mathrm{ppm}): 8.88$ (unres. dd, $\left.1 \mathrm{H}, H_{\mathrm{m}}\right), 8.29-8.23\left(\mathrm{~m}, 2 \mathrm{H}, H_{\mathrm{j}, \mathrm{k}}\right), 7.73$ $\left(\mathrm{d},{ }^{3} J=8.1 \mathrm{~Hz}, 1 \mathrm{H}, H_{\mathrm{f}}\right), 7.66\left(\mathrm{~d},{ }^{3} \mathrm{~J}=8.1 \mathrm{~Hz}, 1 \mathrm{H}, H_{\mathrm{c}}\right), 7.35\left(\mathrm{t},{ }^{3} J=7.6 \mathrm{~Hz}\right.$, $\left.1 \mathrm{H}, H_{\mathrm{d}}\right), 7.29\left(\mathrm{t},{ }^{3} \mathrm{~J}=7.6 \mathrm{~Hz}, 1 \mathrm{H}, H_{\mathrm{e}}\right), 4.21\left(\mathrm{~s}, 3 \mathrm{H}, H_{\mathrm{a}}\right) .{ }^{13} \mathrm{C} \mathrm{NMR}$ $\left(151 \mathrm{MHz}\right.$, DMSO- $\left.d_{6}, 298 \mathrm{~K}\right) \delta(\mathrm{ppm}): 149.6\left(C_{\mathrm{m}}\right), 148.8\left(C_{\mathrm{h}}\right), 148.7\left(C_{\mathrm{i}}\right)$, $142.0\left(C_{\mathrm{b}}\right), 140.1\left(C_{\mathrm{k}}\right), 137.2\left(C_{\mathrm{g}}\right), 126.0\left(C_{\mathrm{j}}\right), 123.4\left(C_{\mathrm{d}}\right), 122.5\left(C_{\mathrm{e}}\right)$, $120.9\left(C_{1}\right), 119.5\left(C_{f}\right), 110.9\left(C_{c}\right), 32.7\left(C_{a}\right) . M S(E l, 70 \mathrm{eV}) \mathrm{m} / \mathrm{z}: 288.01$ (100) $\left[\mathrm{M}^{+}\right.$. HRMS (ESI) m/z: $288.01275[\mathrm{M}+\mathrm{H}]^{+}$(calculated: 288.01309 for $\mathrm{C}_{13} \mathrm{H}_{11} \mathrm{~N}_{3} \mathrm{Br}$ ). FT-IR: $\tilde{v}=3041(\mathrm{w}), 1434(\mathrm{~m}), 1004(\mathrm{~m})$, 727 (s) $\mathrm{cm}^{-1}$. M.p.: $137^{\circ} \mathrm{C}$.

1,2-Di(6"'-(1'-methyl-1H-benzo[d]imidazol-2'-yl)pyridin-3"'-yl) ethyne (2 b): 2-(5'-Bromopyridin-2'-yl)-1-methyl-1H-benzo[d] 
imidazole (6 b) (208 mg, $722 \mu \mathrm{mol})$ and $\mathrm{Pd}\left(\mathrm{PPh}_{3}\right)_{4}(41.8 \mathrm{mg}, 5 \mathrm{~mol} \%)$ were added to a pressure tube and evacuated for five minutes. Using counterflow technique, degassed tetrabutylammonium fluoride ( $1 \mathrm{M}$ in tetrahydrofuran, $4.30 \mathrm{~mL}, 4.30 \mathrm{mmol}$ ) and trimethylsilylacetylene $(100 \mu \mathrm{L}, 723 \mu \mathrm{mol})$ were added, the tube was immediately closed and the reaction mixture was heated at $70^{\circ} \mathrm{C}$ for $3 \mathrm{~h}$. The product precipitated, was filtered and washed with cold tetrahydrofuran $(100 \mathrm{~mL})$. The product was obtained as a yellow to green solid $(112 \mathrm{mg}, 254 \mu \mathrm{mol}, 70 \%)$ : ${ }^{1} \mathrm{H}$ NMR $\left(600 \mathrm{MHz}, \mathrm{CDCl}_{3}\right.$, $298 \mathrm{~K}) \delta(\mathrm{ppm}): 8.87\left(\mathrm{~d},{ }^{4} J=1.9 \mathrm{~Hz}, 2 \mathrm{H}, H_{\mathrm{m}}\right), 8.48\left(\mathrm{~d},{ }^{3} J=8.2 \mathrm{~Hz}, 2 \mathrm{H}\right.$, $\left.H_{\mathrm{j}}\right), 8.00\left(\mathrm{dd},{ }^{3} \mathrm{~J}=8.2 \mathrm{~Hz},{ }^{4} J=1.9 \mathrm{~Hz}, 2 \mathrm{H}, H_{\mathrm{k}}\right), 7.85\left(\mathrm{~d},{ }^{3} J=7.8 \mathrm{~Hz}, 2 \mathrm{H}\right.$, $\left.H_{\mathrm{f}}\right), 7.47\left(\mathrm{~d},{ }^{3} \mathrm{~J}=7.8 \mathrm{~Hz}, 2 \mathrm{H}, H_{\mathrm{c}}\right), 7.39-7.32\left(\mathrm{~m}, 4 \mathrm{H}, H_{\mathrm{d}, \mathrm{e}}\right), 4.32(\mathrm{~s}, 6 \mathrm{H}$, $\left.H_{\mathrm{a}}\right) .{ }^{13} \mathrm{C}$ NMR $\left(126 \mathrm{MHz}, \mathrm{CDCl}_{3}, 298 \mathrm{~K}\right) \delta(\mathrm{ppm}): 151.1\left(C_{\mathrm{m}}\right), 149.8\left(C_{\mathrm{i}}\right)$, $149.4\left(C_{\mathrm{l}}\right), 142.6\left(C_{\mathrm{g}}\right), 139.2\left(C_{\mathrm{k}}\right), 137.4\left(C_{\mathrm{b}}\right), 124.0\left(C_{\mathrm{j}}\right), 123.7\left(C_{\mathrm{d} / \mathrm{e}}\right)$, $122.9\left(C_{\mathrm{d} / \mathrm{e}}\right), 120.2\left(C_{\mathrm{f}}\right), 119.5\left(C_{\mathrm{h}}\right), 110.0\left(C_{\mathrm{c}}\right), 90.7\left(C_{\mathrm{n}}\right), 32.9\left(C_{\mathrm{a}}\right)$. HRMS (El, $70 \mathrm{eV}$ ) $\mathrm{m} / \mathrm{z}: 440.17491[\mathrm{M}]^{+}$(calculated: 440.17494 for $\mathrm{C}_{28} \mathrm{H}_{20} \mathrm{~N}_{6}$ ). FT-IR: $\tilde{v}=3050$ (w), $1466(\mathrm{~m}), 725$ (s) $\mathrm{cm}^{-1}$. M. p.: decomposed at $>220^{\circ} \mathrm{C}$.

2-(5'-Bromopyridin-2'-yl)-1-benzyl-1H-benzo[d]imidazole (6c): 2(5'-Bromopyridin-2'-yl)-1H-benzo[d]imidazole (6a) (614 mg, $2.24 \mathrm{mmol}$ ) and potassium carbonate (milled, $496 \mathrm{mg}, 3.59 \mathrm{mmol}$ ) were dissolved in dry dimethylformamide $(5 \mathrm{~mL})$. Benzyl bromide ( $350 \mu \mathrm{L}, 2.94 \mathrm{mmol}$ ) was added and the reaction mixture stirred at room temperature for $4.5 \mathrm{~h}$. The solvent was removed in vacuo $\left(55^{\circ} \mathrm{C}, 20 \mathrm{mbar}\right)$. Water $(50 \mathrm{~mL})$ was added and the aqueous layer was extracted with ethyl acetate $(1 \times 50 \mathrm{~mL})$. The organic layers were combined, washed with brine $(2 \times 125 \mathrm{~mL})$ and sodium hydroxide solution $(10 \%, 1 \times 50 \mathrm{~mL})$, dried over magnesium sulfate and the solvent was removed in vacuo. The product was obtained as a greyish solid $(663 \mathrm{mg}, 1.82 \mathrm{mmol}, 81 \%)$ : ${ }^{1} \mathrm{H}$ NMR $(600 \mathrm{MHz}$, DMSO- $\left._{6}, 298 \mathrm{~K}\right) \delta(\mathrm{ppm}): 8.82\left(\mathrm{dd},{ }^{4} J=2.3 \mathrm{~Hz},{ }^{5} J=0.6 \mathrm{~Hz}, 1 \mathrm{H}, H_{\mathrm{q}}\right)$, $8.32\left(\mathrm{dd},{ }^{3} \mathrm{~J}=8.6 \mathrm{~Hz}, 5 \mathrm{~J}=0.6 \mathrm{~Hz}, 1 \mathrm{H}, H_{\mathrm{n}}\right), 8.25\left(\mathrm{dd},{ }^{3} J=8.6 \mathrm{~Hz},{ }^{4} J=\right.$ $\left.2.3 \mathrm{~Hz}, 1 \mathrm{H}, H_{\mathrm{o}}\right), 7.78-7.74\left(\mathrm{~m}, 1 \mathrm{H}, H_{\mathrm{i}}\right), 7.61-7.57\left(\mathrm{~m}, 1 \mathrm{H}, H_{\mathrm{h}}\right), 7.32-7.26$ $\left(\mathrm{m}, 2 \mathrm{H}, H_{\mathrm{g}, \mathrm{j}}\right), 7.26-7.22\left(\mathrm{~m}, 2 \mathrm{H}, H_{\mathrm{b}}\right), 7.20-7.17\left(\mathrm{~m}, 1 \mathrm{H}, H_{\mathrm{a}}\right), 7.14-7.11$ $\left(\mathrm{m}, 2 \mathrm{H}, H_{\mathrm{c}}\right), 6.17\left(\mathrm{~s}, 2 \mathrm{H}, H_{\mathrm{e}}\right) .{ }^{13} \mathrm{C}$ NMR $\left(151 \mathrm{MHz}, \mathrm{DMSO}-d_{6}, 298 \mathrm{~K}\right) \delta$ (ppm): $149.6\left(C_{\mathrm{q}}\right), 148.6\left(C_{\mathrm{l}}\right), 148.4\left(C_{\mathrm{m}}\right), 142.2\left(C_{\mathrm{c}}\right), 140.3\left(C_{\mathrm{o}}\right), 137.7$ $\left(C_{\mathrm{d}}\right), 136.6\left(C_{\mathrm{k}}\right), 128.6\left(C_{\mathrm{b}}\right), 127.3\left(C_{\mathrm{a}}\right), 126.7\left(C_{\mathrm{c}}\right), 126.0\left(C_{\mathrm{n}}\right), 123.8\left(C_{\mathrm{j} / \mathrm{g}}\right.$ )$, 122.9\left(C_{\mathrm{j} / \mathrm{g}}\right), 121.2\left(C_{\mathrm{p}}\right), 119.8\left(C_{\mathrm{i}}\right), 111.5\left(C_{\mathrm{h}}\right), 48.1\left(C_{\mathrm{e}}\right) . \mathrm{MS}(\mathrm{EI}, 70 \mathrm{eV})$ $\mathrm{m} / \mathrm{z}: 364.02(100) \quad[\mathrm{M}]^{+}$. HRMS (ESI) $\mathrm{m} / \mathrm{z}: 364.04380 \quad[\mathrm{M}+\mathrm{H}]^{+}$ (calculated: 364.04439 for $\mathrm{C}_{19} \mathrm{H}_{15} \mathrm{~N}_{3} \mathrm{Br}$ ). FT-IR: $\tilde{v}=3252.9$ (w), 2158.9 $(w), 1572.4(w), 1496.22(w), 1434.8(m), 1407.8(m), 1328.6(m)$, $1291.5(\mathrm{w}), 1259.3(\mathrm{w}), 1236.2(\mathrm{~m}), 1157.5(\mathrm{~m}), 1089.5(\mathrm{~m}), 1009.8$ $(\mathrm{m}), 977.5(\mathrm{w}), 923.7(\mathrm{w}), 845.9(\mathrm{~m}), 778.1(\mathrm{w}), 763.1(\mathrm{~m}), 736.7(\mathrm{~s})$, 717.9 (s), $692.8(\mathrm{~m}), 641.8$ (w) $\mathrm{cm}^{-1}$. M. p.: $131^{\circ} \mathrm{C}$.

\section{1,2-Di(6"-(1'-benzyl-1H-benzo[d]imidazol-2'-yl)pyridin-3"'-yl)}

ethyne (2c): 2-(5'-Bromopyridin-2'-yl)-1-benzyl-1H-benzo[d] imidazole (6c) (263 mg, $722 \mu \mathrm{mol})$ and $\mathrm{Pd}\left(\mathrm{PPh}_{3}\right)_{4}(41.8 \mathrm{mg}, 5 \mathrm{~mol} \%)$ were added to a pressure tube and evacuated for five minutes. Using counterflow technique, degassed tetrabutylammonium fluoride ( $1 \mathrm{M}$ in tetrahydrofuran, $4.30 \mathrm{~mL}, 4.30 \mathrm{mmol}$ ) and trimethylsilylacetylene $(100 \mu \mathrm{L}, 723 \mu \mathrm{mol})$ were added, the tube was immediately closed and the reaction mixture was heated at $70^{\circ} \mathrm{C}$ for $3 \mathrm{~h}$. The product precipitated, was filtered and washed with cold tetrahydrofuran $(1 \times 200 \mathrm{~mL})$. The product was obtained as a neon green solid (196 mg, $331 \mu \mathrm{mol}, 92 \%):{ }^{1} \mathrm{H}$ NMR $\left(500 \mathrm{MHz}\right.$, TFA- $d_{1}$, $298 \mathrm{~K}) \delta(\mathrm{ppm}): 9.42\left(\mathrm{dd},{ }^{4} J=2.0 \mathrm{~Hz},{ }^{5} J=0.8 \mathrm{~Hz}, 2 \mathrm{H}, H_{\mathrm{q}}\right), 8.65$ (dd, $\left.{ }^{3} J=8.2 \mathrm{~Hz},{ }^{4} J=2.0 \mathrm{~Hz}, 2 \mathrm{H}, H_{\mathrm{o}}\right), 8.41\left(\mathrm{dd},{ }^{3} J=8.2 \mathrm{~Hz},{ }^{5} J=0.8 \mathrm{~Hz}, 2 \mathrm{H}\right.$, $\left.H_{\mathrm{n}}\right), 8.21\left(\mathrm{~d},{ }^{3} \mathrm{~J}=7.8 \mathrm{~Hz}, 2 \mathrm{H}, H_{\mathrm{j}}\right), 8.09-8.00\left(\mathrm{~m}, 6 \mathrm{H}, H_{\mathrm{g}, \mathrm{h}, \mathrm{i}}\right), 7.64-7.59(\mathrm{~m}$, $\left.4 \mathrm{H}, H_{\mathrm{a}, \mathrm{b}}\right), 7.45-7.40\left(\mathrm{~m}, 2 \mathrm{H}, H_{\mathrm{c}}\right), 6.18\left(\mathrm{~s}, 4 \mathrm{H}, H_{\mathrm{e}}\right) .{ }^{13} \mathrm{C}$ NMR $(126 \mathrm{MHz}$, TFA- $\left.d_{1}, 298 \mathrm{~K}\right) \delta(\mathrm{ppm}): 154.8\left(C_{\mathrm{q}}\right), 147.1\left(C_{\mathrm{l}}\right), 145.3\left(C_{\mathrm{o}}\right), 141.6\left(C_{\mathrm{m}}\right)$, $135.6\left(C_{\mathrm{f}}\right), 134.5\left(C_{\mathrm{d}}\right), 132.6\left(C_{\mathrm{k}}\right), 132.0\left(C_{\mathrm{a} / \mathrm{b}}\right), 131.9\left(C_{\mathrm{a} / \mathrm{b}}\right), 131.7\left(C_{\mathrm{h} / \mathrm{i}}\right)$, $131.2\left(C_{\mathrm{h} / \mathrm{i}}\right), 128.8\left(C_{\mathrm{n}}\right), 128.6\left(C_{\mathrm{c}}\right), 126.8\left(C_{\mathrm{p}}\right), 117.0\left(C_{\mathrm{j}}\right), 115.6\left(C_{\mathrm{g}}\right)$, $93.4\left(C_{\mathrm{r}}\right), 52.8\left(C_{\mathrm{e}}\right)$. HRMS (El, $\left.70 \mathrm{eV}\right) \mathrm{m} / \mathrm{z}: 592.23610[\mathrm{M}]^{+}$(calculated: 592.23754 for $\mathrm{C}_{40} \mathrm{H}_{28} \mathrm{~N}_{6}$ ). FT-IR: $\tilde{v}=1972.9(\mathrm{w}), 1592.1(\mathrm{w}), 1519.5(\mathrm{w})$, $1495.9(\mathrm{w}), 1465.8(\mathrm{~m}), 1442.3(\mathrm{~m}), 1405.5(\mathrm{~m}),(\mathrm{w}), 1368.3(\mathrm{~m})$, $1330.4(m), 1296.8(s), 1240.1(w), 1166.5(w), 1069.5(w), 853.7(m)$, $743.2(\mathrm{~s}), 726.1(\mathrm{~s}), 452.3(\mathrm{~m}) \mathrm{cm}^{-1}$. M. p.: $>300^{\circ} \mathrm{C}$.

\section{Acknowledgements}

We thank the Deutsche Forschungsgemeinschaft (DFG, project numbers 413396832 and 429518153) for financial support. We thank the spectroscopy department and Dr. Claus Bier for NMR and mass spectral data collection. We thank Felix Piontek and Etienne Rommens for preliminary studies and Niclas Grocholski for the synthesis of additional ligand. Open access funding enabled and organized by Projekt DEAL.

\section{Conflict of Interest}

The authors declare no conflict of interest.

Keywords: Cross-coupling • Metal-organic cages • One-pot reactions · Sonogashira coupling $\cdot$ Supramolecular chemistry

[1] A. Biffis, P. Centomo, A. Del Zotto, M. Zecca, Chem. Rev. 2018, 118, 2249-2295.

[2] a) R. Chinchilla, C. Najera, Chem. Rev. 2007, 107, 874-922; b) R. Chinchilla, C. Najera, Chem. Soc. Rev. 2011, 40, 5084-5121; c) K. Sonogashira, Y. Tohda, N. Hagihara, Tetrahedron Lett. 1975, 16, 44674470.

[3] D. Wang, S. H. Gao, Org. Chem. Front. 2014, 1, 556-566.

[4] a) J. M. Tour, Acc. Chem. Res. 2000, 33, 791-804; b) U. H. F. Bunz, Chem. Rev. 2000, 100, 1605-1644.

[5] a) D. Zare, B. Doistau, H. Nozary, C. Besnard, L. Guenee, Y. Suffren, A. L. Pele, A. Hauser, C. Piguet, Dalton Trans. 2017, 46, 8992-9009; b) R. L. Greenaway, V. Santolini, M. J. Bennison, B. M. Alston, C. J. Pugh, M. A. Little, M. Miklitz, E. G. B. Eden-Rump, R. Clowes, A. Shakil, H. J. Cuthbertson, H. Armstrong, M. E. Briggs, K. E. Jelfs, A. I. Cooper, Nat. Commun. 2018, 9, 2849; c) R. J. Marshall, T. Richards, C. L. Hobday, C. F. Murphie, C. Wilson, S. A. Moggach, T. D. Bennett, R. S. Forgan, Dalton Trans. 2016, 45, 4132-4135; d) S. Ø. Scottwell, A. B. S. Elliott, K. J. Shaffer, A. Nafady, C. J. McAdam, K. C. Gordon, J. D. Crowley, Chem. Commun. 2015, 51, 8161-8164; e) S. M. Kopp, H. Gotfredsen, J.-R. Deng, T. D. W. Claridge, H. L. Anderson, J. Am. Chem. Soc. 2020, 142, 19393-19401; f) M. Lehr, T. Paschelke, E. Trumpf, A. M. Vogt, C. Näther, F. D. Sönnichsen, A. J. McConnell, Angew. Chem. Int. Ed. 2020, 59, 1934419351 ; g) P. Liao, B. W. Langloss, A. M. Johnson, E. R. Knudsen, F. S. Tham, R. R. Julian, R. J. Hooley, Chem. Commun. 2010, 46, 4932-4934; h) P. Bonakdarzadeh, F. F. Pan, E. Kalenius, O. Jurcek, K. Rissanen, Angew. Chem. Int. Ed. 2015, 54, 14890-14893; Angew. Chem. 2015, 127, 1510315106 ; i) S. M. Jansze, K. Severin, J. Am. Chem. Soc. 2019, 141, 815-819; j) M. Kaseborn, J. J. Holstein, G. H. Clever, A. Lutzen, Angew. Chem. Int. Ed. 2018, 57, 12171-12175; k) R. A. Bilbeisi, J. K. Clegg, N. Elgrishi, X. de Hatten, M. Devillard, B. Breiner, P. Mal, J. R. Nitschke, J. Am. Chem. Soc. 2012, 134, 5110-5119; I) Y. Domoto, M. Abe, T. Kikuchi, M. Fujita, Angew. Chem. Int. Ed. 2020, 59, 3450-3454; m) J. E. M. Lewis, A. Tarzia, A. J. P. White, K. E. Jelfs, Chem. Sci. 2020, 11, 677-683.

[6] a) V. Vij, V. Bhalla, M. Kumar, Chem. Rev. 2016, 116, 9565-9627; b) S. Suzuki, Y. Segawa, K. Itami, J. Yamaguchi, Nat. Chem. 2015, 7, 227-233.

[7] O. Shynkaruk, Y. Y. Qi, A. Cottrell-Callbeck, W. T. Delgado, R. McDonald, M. J. Ferguson, G. He, E. Rivard, Organometallics 2016, 35, 2232-2241.

[8] G. He, B. D. Wiltshire, P. Choi, A. Savin, S. Sun, A. Mohammadpour, M. J. Ferguson, R. McDonald, S. Farsinezhad, A. Brown, K. Shankar, E. Rivard, Chem. Commun. 2015, 51, 5444-5447.

[9] a) C. Glaser, Ber. Dtsch. Chem. Ges. 1869, 2, 422-424; b) A. S. Hay, J. Org. Chem. 1960, 25, 1275-1276; c) A. S. Hay, J. Org. Chem. 1962, 27, 33203321.

[10] A. Elangovan, Y. H. Wang, T. I. Ho, Org. Lett. 2003, 5, 1841-1844. 
[11] a) C.-J. Li, D.-L. Chen, C. W. Costello, Org. Process Res. Dev. 1997, 1, 325327; b) M. lyoda, A. Vorasingha, Y. Kuwatani, M. Yoshida, Tetrahedron Lett. 1998, 39, 4701-4704; c) S. Krompiec, M. Filapek, I. Grudzka-Flak, A. Slodek, S. Kula, J. G. Malecki, J. Malarz, G. Szafraniec-Gorol, M. Penkala, E. Schab-Balcerzak, M. Paluch, M. Mierzwa, M. Matussek, A. Szlapa, M. Pajak, D. Blach, B. Marcol, W. Danikiewicz, B. Boharewicz, A. Iwan, Molecules 2015, 20, 4565-4593.

[12] W. Zhang, H. Wu, Z. Liu, P. Zhong, L. Zhang, X. Huang, J. Cheng, Chem. Commun. 2006, 4826-4828.

[13] J. Moon, M. Jeong, H. Nam, J. Ju, J. H. Moon, H. M. Jung, S. Lee, Org. Lett. 2008, 10, 945-948.

[14] a) M. J. Mio, L. C. Kopel, J. B. Braun, T. L. Gadzikwa, K. L. Hull, R. G. Brisbois, C. J. Markworth, P. A. Grieco, Org. Lett. 2002, 4, 3199-3202; b) J. Gil-Molto, C. Najera, Adv. Synth. Catal. 2006, 348, 1874-1882; c) S. Z. Qiu, C. Y. Zhang, R. Qiu, G. D. Yin, J. K. Huang, Adv. Synth. Catal. 2018, 360, 313-321.

[15] a) A. Mori, J. Kawashima, T. Shimada, M. Suguro, K. Hirabayashi, Y. Nishihara, Org. Lett. 2000, 2, 2935-2937; b) Y. Liang, Y. X. Xie, J. H. Li, J. Org. Chem. 2006, 71, 379-381; c) G. Hamasaka, D. Roy, A. Tazawa, Y. Uozumi, ACS Catal. 2019, 9, 11640-11646; d) B. Jin, F. Gallou, J. Reilly, B. H. Lipshutz, Chem. Sci. 2019, 10, 3481-3485; e) S. Handa, J. D. Smith, Y. Zhang, B. S. Takale, F. Gallou, B. H. Lipshutz, Org. Lett. 2018, 20, 542545; f) Q. Chen, F. Gao, H. Tang, M. Yao, Q. Zhao, Y. Shi, Y. Dang, C. Cao, ACS Catal. 2019, 9, 3730-3736.
[16] a) V. Grosshenny, R. Ziessel, Tetrahedron Lett. 1992, 33, 8075-8078; b) M. Kim, C. H. Kang, S. Hong, W. Y. Lee, B. H. Kim, Inorg. Chim. Acta 2013, 395, 145-150; c) V. Grosshenny, F. M. Romero, R. Ziessel, J. Org. Chem. $1997,62,1491-1500$.

[17] R. W. Friesen, E. M. D. Allouche, in Encyclopedia of Reagents for Organic Synthesis, 2017, pp. 1-7.

[18] a) S. Ladouceur, A. M. Soliman, E. Zysman-Colman, Synthesis 2011, 3604-3611; b) A. M. Soliman, D. Fortin, P. D. Harvey, E. Zysman-Colman, Chem. Commun. 2012, 48, 1120-1122.

[19] Due to precipitation of the ligand from the reaction mixture, these ligands could be isolated without the need for purification by column chromatography.

[20] M. Kuss-Petermann, O. S. Wenger, J. Phys. Chem. A 2013, 117, 57265733.

[21] J. Jia, C. Jiang, X. Zhang, Y. Jiang, D. Ma, Tetrahedron Lett. 2011, 52, 5593-5595.

[22] M. Lin, Q. Tang, H. Zeng, G. Xing, Q. Ling, Russ. J. Gen. Chem. 2016, 86, 1747-1752.

Manuscript received: March 5, 2021

Revised manuscript received: March 5, 2021

Accepted manuscript online: March 9, 2021 